\title{
Synthesis and characterization of $\left[\operatorname{Zn}(\text { acetate })_{2}(\operatorname{amine})_{x}\right]$ compounds $(x=1$ or 2$)$ and their use as precursors to $\mathrm{ZnO}$
}

\author{
Jesse S. Hyslop ${ }^{1}$, Amanda R. Boydstun ${ }^{1}$, Theron R. Fereday ${ }^{1}$, Joanna R. Rusch ${ }^{1}$, Jennifer L. \\ Strunk $^{1}$, Christian T. Wall ${ }^{1}$, Cecelia C. Pena ${ }^{1}$, Nicholas L. McKibben ${ }^{1}$, Jerry D. Harris ${ }^{1}, *$, Aaron \\ Thurber $^{2}$, Alex Punnoose ${ }^{2}$, Jason Brotherton ${ }^{3}$, Pamela Walker ${ }^{3}$, Lloyd Lowe ${ }^{3}$, Blake Rapp ${ }^{3}$, \\ Shem Purnell ${ }^{3}$, William B. Knowlton ${ }^{3}$, Seth M. Hubbard ${ }^{4}$, and Brian J. Frost ${ }^{5}$ \\ ${ }^{1}$ Department of Chemistry, Northwest Nazarene University, Nampa, Idaho 83686 \\ ${ }^{2}$ Department of Physics, Boise State University, Boise, Idaho 83752 \\ ${ }^{3}$ Department Materials Science \& Engineering, Department of Electrical and Computer \\ Engineering, Boise State University, Boise, Idaho 83752 \\ ${ }^{4}$ Department of Physics, Rochester Institute of Technology, Rochester, New York 14623 \\ ${ }^{5}$ Department of Chemistry, University of Nevada, Reno, NV 89557
}

\begin{abstract}
As an obvious candidate for a p-type dopant in $\mathrm{ZnO}$, nitrogen remains elusive in this role. Nitrogen containing precursors are a potential means to incorporate nitrogen during MOCVD growth. One class of nitrogen-containing precursors are zinc acetate amines, yet, they have received little attention. The synthesis and single crystal X-ray structure of [Zn(acetate $\left.)_{2}(\mathrm{en})\right]$, and the synthesis of $\left[\mathrm{Zn}(\text { acetate })_{2}(\mathrm{en})_{2}\right],\left[\mathrm{Zn}(\text { acetate })_{2}(\text { benzylamine })_{2}\right]$, $\left[\mathrm{Zn}(\text { acetate })_{2}(\text { butylamine })_{2}\right],\left[\mathrm{Zn}(\text { acetate })_{2}\left(\mathrm{NH}_{3}\right)_{2}\right]$, and $\left[\mathrm{Zn}(\text { acetate })_{2}(\text { tris })_{2}\right]$, where en $=$ ethylenediamine and tris $=$ (tris[hydroxymethyl]aminomethane) are reported. The compounds were characterized by thermogravimetric analysis and pyrolyzed in air and inert gas to yield $\mathrm{ZnO}$. These compounds are useful single source precursors to $\mathrm{ZnO}$ bulk powders by alkali precipitation and $\mathrm{ZnO}$ thin films by spray pyrolysis. The amine bound to the zinc influences the $\mathrm{ZnO}$ crystal size and shape and acts as a nitrogen donor for preparing nitrogen-doped $\mathrm{ZnO}$ during alkali precipitation. Thin films of $\mathrm{ZnO}$ prepared by spray pyrolysis using the precursors had a (100) preferred orientation and measured n-type to intrinsic conductivity.
\end{abstract}

KEYWORDS: ZnO, single source precursors, crystal structure

*Corresponding author.

J.D. Harris: Northwest Nazarene University

Department of Chemistry

623 S. University Blvd.

Nampa, ID 83686

Tel.: $1-208-467-8883$

Fax: 1-208-467-8676

Email: jdharris@nnu.edu 


\section{Introduction}

Zinc oxide has received much interest in recent years because of its attractive electronic properties, ease of synthesis, low cost and for being more environmentally friendly than some alternative materials. These properties make it the material of choice for use in applications such as, but not limited to photovoltaics [1], photoacoustic wave devices [2], gas sensors [3], devices requiring a transparent conductive oxide [4], uses in biomedical applications [5-7], photocatalysis [8, 9], and as a UV absorber in many sunscreens. Military interest in $\mathrm{ZnO}$ arises from its potential use in UV transceivers [10], and for space electronics applications due to its superior "radiation hardness" over other semiconductors [11]. The prediction that manganese doped $\mathrm{ZnO}$ would exhibit room-temperature carrier-mediated ferromagnetism spurred more interest in the material [12]. The development of dilute magnetically doped semiconductors, with magnetic spins that can be manipulated at or above room temperature, is essential for the development of spin-based electronics (spintronics), and transparent semiconductors, such as $\mathrm{ZnO}$, offer great potential for the development of these magnetic-optical-electronic devices [13].

For many of the electronic applications, p-type $\mathrm{ZnO}$ would be critical to their implementation. As typically grown, $\mathrm{ZnO}$ is n-type because of donors from impurities and defects [14]. Doping $\mathrm{ZnO}$ with elements containing fewer valence electrons than oxygen, such as nitrogen or phosphorous, introduces acceptors that compensate the intrinsic donors. Many groups have prepared nitrogen doped $\mathrm{ZnO}$ by numerous routes, including sputtering [15-17], laser ablation [18], molecular beam epitaxy [19], chemical vapor deposition [20], sol-gel synthesis [21], hydrothermal synthesis [22], spray pyrolysis [23], ball milling and combustions techniques $[24,25]$. Additionally, many of the applications require processing control of particle size and morphology, as size and shape of the crystals can alter electronic, optical and chemical 
properties of the material [26]. Crystals of $\mathrm{ZnO}$ have been prepared in a vast array of sizes and shapes, including nanotubes [27], nanowires [28], nanorods [28], nanosheets [29], plates [30], and exotic snowflake- and flower-like structures [31, 32]. For solution-based synthesis, $\mathrm{ZnO}$ crystal size and shape have been influenced by not only synthesis method (hydrothermal, sol-gel, precipitation, etc.) but also solvent [30], time of precipitation [32], ions and molecules present during precipitation and growth [33-35], and annealing temperature and time [36, 37].

This research explores the use of $\left[\operatorname{Zn}(\text { acetate })_{2}(\text { amine })_{x}\right](x=1$ or 2$)$ compounds as single source precursors to $\mathrm{ZnO}$ films and bulk powders, and the use of the different amines to modify morphology, crystal size, and $\mathrm{ZnO}$ formation temperature. The ability of the amine to act as a nitrogen donor to yield nitrogen doped $\mathrm{ZnO}$ was also explored. The precursors prepared were [Zn(acetate $)_{2}($ en $\left.)\right],\left[\mathrm{Zn}(\text { acetate })_{2}(\mathrm{en})_{2}\right],\left[\mathrm{Zn}(\text { acetate })_{2}(\text { benzylamine })_{2}\right],\left[\mathrm{Zn}(\text { acetate })_{2}(\text { butylamine })_{2}\right]$, $\left[\mathrm{Zn}(\text { acetate })_{2}\left(\mathrm{NH}_{3}\right)_{2}\right]$, and $\left[\mathrm{Zn}(\text { acetate })_{2}(\text { tris })_{2}\right]$, where en $=$ ethylenediamine and tris $=$

(tris[hydroxymethyl]aminomethane). The synthesis of $\left[\mathrm{Zn}(\text { acetate })_{2}\left(\mathrm{NH}_{3}\right)_{2}\right]$ has been previously reported [38], but this is the first report of the synthesis of the others. This paper is also the first reported use of $\left[\mathrm{Zn}(\text { acetate })_{2}(\text { amine })_{\mathrm{x}}\right]$ compounds to prepare $\mathrm{ZnO}$. The synthesis and characterization of these compounds are straightforward, making them convenient compounds to prepare and use as chemical precursors to $\mathrm{ZnO}$. Crystal morphology of bulk $\mathrm{ZnO}$ powders can be tuned from needles to plates by using different amines.

\section{Experimental Procedure}

Techniques and Materials. Zinc acetate dihydrate (Fisher Chemicals) was used without further purification. Amines were either used as received or distilled under nitrogen prior to use. All synthesis was done at room temperature under ambient conditions unless otherwise stated. Solvents were either ACS or HPLC grade and used as received. Ultrapure water for reactions 
was obtained from a Millipore Milli-Q system. Melting points were measured in a nitrogen filled glovebox. All NMR spectra were measured on a Varian Mercury $300 \mathrm{MHz}$ Spectrometer.

Synthesis of $\left[\mathrm{Zn}(\text { acetate })_{2}(\right.$ ethylenediamine $\left.)\right] \bullet 1.6 \mathrm{H}_{2} \mathrm{O}(1)$. Zinc acetate dihydrate (4.5068g, $20.5 \mathrm{mmol})$ and ethylenediamine $(1.38 \mathrm{ml}, 20.6 \mathrm{mmol})$ were dissolved in water (25 $\mathrm{mL}$ ). The solution was stirred for three days and then evacuated to dryness. The product was washed with dichloromethane $(15 \mathrm{ml})$ then filtered and washed with additional dichloromethane $(2 \times 5 \mathrm{ml})$ to give a fine, white powder. Yield: $3.9554 \mathrm{~g}(95.4 \%)$. Soluble in methanol and ethanol. Mp: $181-187^{\circ} \mathrm{C}$. Elem. Anal. for $\mathrm{ZnC}_{6} \mathrm{H}_{17.2} \mathrm{~N}_{2} \mathrm{O}_{5.6}: \mathrm{C}=26.46 ; \mathrm{H}=6.36 ; \mathrm{N}=10.22 \%$. Found: $\mathrm{C}=26.67 ; \mathrm{H}=6.73 ; \mathrm{N}=10.23 \% .{ }^{1} \mathrm{H} \mathrm{NMR}\left(\mathrm{CD}_{3} \mathrm{OD}\right): \delta 1.954\left(\mathrm{~s}, 6 \mathrm{H}, \mathrm{OOCCH}_{3}\right) ; 2.802$ (s,4H, $\mathrm{H}_{2} \mathrm{NCH}_{2} \mathrm{CH}_{2} \mathrm{NH}_{2}$ ). Crystals suitable for $\mathrm{X}$-ray diffraction were grown by slow evaporation of an ethanol solution of the product.

Synthesis of $\left[\mathrm{Zn}(\text { acetate })_{2}(\text { ethylenediamine })_{2}\right]$ (2). Zinc acetate dihydrate $(0.9986 \mathrm{~g}$, $4.55 \mathrm{mmol})$ and ethylenediamine $(0.61 \mathrm{ml}, 8.96 \mathrm{mmol})$ dissolved in anhydrous ethanol $(20 \mathrm{~mL})$. The solution was stirred overnight and then evacuated to dryness. The product was dried at $100^{\circ} \mathrm{C}$ for 30 minutes in a nitrogen flow containing a partial pressure of the ethylenediamine, which was generated by bubbling the nitrogen through the amine. Yield: $1.0705 \mathrm{~g}(77 \%)$ of cream colored powder. Soluble in water and alcohols. Mp: $155-160^{\circ} \mathrm{C}$. Elem. Anal. for $\mathrm{ZnC}_{8} \mathrm{H}_{22} \mathrm{~N}_{4} \mathrm{O}_{4}: \mathrm{C}=31.64 ; \mathrm{H}=7.30 ; \mathrm{N}=18.45 \%$. Found: $\mathrm{C}=31.52 ; \mathrm{H}=7.40 ; \mathrm{N}=18.49 \%$. ${ }^{1} \mathrm{H}$ NMR (CD $3 \mathrm{OD}): \delta 1.921\left(\mathrm{~s}, 6 \mathrm{H}, \mathrm{OOCCH}_{3}\right) ; 2.737\left(\mathrm{~s}, 8 \mathrm{H}, \mathrm{H}_{2} \mathrm{NCH}_{2} \mathrm{CH}_{2} \mathrm{NH}_{2}\right)$.

Synthesis of [Zn(acetate) $\left.)_{2}(\text { tris })_{2}\right]$ (3). Zinc acetate dihydrate (1.0313 g, $\left.47 \mathrm{mmol}\right)$ and tris[hydroxymethyl]aminomethane $(1.1376 \mathrm{~g})$ were dissolved in anhydrous ethanol $(20 \mathrm{~mL})$ in a nitrogen-filled glove box. The solution was stirred for two hours and then was evaporated to dryness under vacuum. Yield: $1.4551 \mathrm{~g}(72.8 \%)$. Soluble in dimethylsulfoxide and water. Mp: 118- $124^{\circ} \mathrm{C}$. Elem. Anal. for $\mathrm{ZnC}_{12} \mathrm{H}_{28} \mathrm{~N}_{2} \mathrm{O}_{10}: \mathrm{C}=33.85 ; \mathrm{H}=6.63 ; \mathrm{N}=6.58 \%$. Found: $\mathrm{C}=$ 
33.89; $\mathrm{H}=6.80 ; \mathrm{N}=6.67 \% .{ }^{1} \mathrm{H} \mathrm{NMR}\left(\mathrm{CD}_{3} \mathrm{OD}\right): \delta 1.727\left(\mathrm{~s}, 6 \mathrm{H}, \mathrm{OOCCH}_{3}\right) ; 3.489$

$\left(\mathrm{s}, 12 \mathrm{H}, \mathrm{C}\left(\mathrm{CH}_{2}\right)_{3}\right)$.

Synthesis of [Zn(acetate) $\left.)_{2}(\text { benzylamine })_{2}\right]$ (4). Zinc acetate dihydrate (0.9966g, 4.54 mmol), benzylamine $(0.98 \mathrm{~mL}, 9.0 \mathrm{mmol})$, and anhydrous ethanol $(20 \mathrm{~mL})$, were added to a round bottom flask. The solution was stirred overnight and then evaporated to dryness. Yield: $1.7055 \mathrm{~g}(94 \%)$ of white powder. Soluble in dimethylsulfoxide and methanol. Mp: $136-143^{\circ} \mathrm{C}$. Elem. Anal. for $\mathrm{ZnC}_{18} \mathrm{H}_{24} \mathrm{~N}_{2} \mathrm{O}_{4}: \mathrm{C}=54.35 ; \mathrm{H}=6.08 ; \mathrm{N}=7.04 \%$. Found: $\mathrm{C}=53.98 ; \mathrm{H}=6.04 ; \mathrm{N}$ $=6.81 \% .{ }^{1} \mathrm{H}$ NMR $\left(\mathrm{CDCl}_{3}\right): \delta 1.952\left(\mathrm{~s}, 6 \mathrm{H}, \mathrm{COCH}_{3}\right) ; 3.584\left(\mathrm{~s}, 4 \mathrm{H}, \mathrm{NH} H_{2}\right) ; 3.844\left(\mathrm{~s}, 4 \mathrm{H}, \mathrm{ph}-\mathrm{CH}_{2} \mathrm{NH}_{2}\right)$ 7.260-7.312 (10H, Benzene ring).

Synthesis of [Zn(acetate) $)_{2}$ (butylamine) $\left.)_{2}\right]$ (5). Zinc acetate dihydrate (1.0287g, 4.69 mmol), butylamine $(0.94 \mathrm{~mL}, 9.5 \mathrm{mmol})$, and anhydrous ethanol $(20 \mathrm{~mL})$, were added to a round bottom flask. The solution was stirred over night and was then evaporated to dryness. The product was dried at $80^{\circ} \mathrm{C}$ for 30 minutes in a nitrogen flow containing a partial pressure of the butylamine, which was generated by bubbling the nitrogen through the amine. Yield: $1.1093 \mathrm{~g}$ (66.9\%). Soluble in chloroform and methanol. Mp: $91-97^{\circ} \mathrm{C}$. Elem. Anal. for $\mathrm{ZnC}_{12} \mathrm{H}_{28} \mathrm{~N}_{2} \mathrm{O}_{4}$ : $\mathrm{C}=43.71 ; \mathrm{H}=8.56 ; \mathrm{N}=8.50 \%$. Found: $\mathrm{C}=43.65 ; \mathrm{H}=8.57 ; \mathrm{N}=8.32 \% .{ }^{1} \mathrm{H} \mathrm{NMR}\left(\mathrm{CDCl}_{3}\right): \delta$ 0.903 (t,6H, $\mathrm{CH}_{3}$ ); 1.286-1.362 (sextet,4H, $\mathrm{CH}_{3} \mathrm{CH}_{2} \mathrm{CH}_{2}$ ); 1.451-1.548 (pentet,4H, $\mathrm{CH}_{2} \mathrm{CH}_{2} \mathrm{CH}_{2}$ ) $1.990\left(\mathrm{~s}, 6 \mathrm{H}, \mathrm{COCH}_{3}\right) ; 2.768\left(\mathrm{t}, 4 \mathrm{H}, \mathrm{CH}_{2} \mathrm{CH}_{2} \mathrm{NH}_{2}\right) ; 2.969$ (s,4H, $\left.\mathrm{NH}_{2}\right)$.

Synthesis of $\left[\mathbf{Z n}(\text { acetate })_{2}\left(\mathbf{N H}_{3}\right)_{2}\right]$ (6). Zinc acetate dihydrate $(10.10 \mathrm{~g}, 46 \mathrm{mmol})$, aqueous ammonia $(10 \mathrm{~mL}, 28 \%)$, and methanol $(25 \mathrm{~mL})$, were added to a round bottom flask. The solution was stirred for six days and then evaporated to dryness in vacuum. The product was dried at $100^{\circ} \mathrm{C}$ for 10 minutes in a flow of $\mathrm{NH}_{3}$. Yield: $10.03 \mathrm{~g}(100 \%)$ as a white powder. Soluble in dimethylsulfoxide and methanol. Mp: $140-148^{\circ} \mathrm{C}$. Elem. Anal. for $\mathrm{ZnC}_{4} \mathrm{H}_{12} \mathrm{~N}_{2} \mathrm{O}_{4}: \mathrm{C}=$ 
22.09; $\mathrm{H}=5.56 ; \mathrm{N}=12.88 \%$. Found: $\mathrm{C}=22.23 ; \mathrm{H}=5.55 ; \mathrm{N}=12.35 \% .{ }^{1} \mathrm{H}$ NMR (DMSO): $\delta$ $1.74\left(\mathrm{~s}, 6 \mathrm{H}, \mathrm{OOCCH}_{3}\right) ; 2.88\left(\mathrm{~s}, 6 \mathrm{H}, \mathrm{NH}_{3}\right)$.

Thermal Analysis. The thermal properties of the precursors and the alkali precipitated $\mathrm{ZnO}$ were measured using a Mettler Toledo TGA/DSC1 thermal analyzer connected to a Pfeiffer ThermoStar mass spectrometer. Thermal characterization was performed in air, nitrogen, argon and vacuum $(0.1 \mathrm{~atm})$, with ramp rates of $10-50^{\circ} \mathrm{C} / \mathrm{min}$ from $50^{\circ} \mathrm{C}$ to $1000^{\circ} \mathrm{C}$.

Bulk pyrolysis of precursors. All six precursors were thermally pyrolyzed in air and under a flow of nitrogen for two hours at temperature. Precursors $\mathbf{1}$ and $\mathbf{2}$ were pyrolyzed at $750^{\circ} \mathrm{C}$, and 3-6 were pyrolyzed at $650-660^{\circ} \mathrm{C}$.

Alkali precipitation of $\mathrm{ZnO}$ powders. Each precursor was added to distilled water maintained at a constant temperature ranging from $65-95^{\circ} \mathrm{C}$. With stirring, $0.6 \mathrm{M} \mathrm{NaOH}$ was added to bring the $\mathrm{pH}$ to 10.00 and cause the $\mathrm{ZnO}$ to precipitate from solution. The $\mathrm{ZnO}$ was then filtered, washed with deionized water, air dried, and then annealed under nitrogen for two hours. Annealing temperatures ranged from $150-300^{\circ} \mathrm{C}$.

X-Ray Powder Diffraction. The materials were characterized by X-ray diffraction (XRD) at room temperature using a Philips X'Pert PRO diffractometer with a $\mathrm{Cu} \mathrm{K} \alpha$ source $(\lambda=$ $1.5418 \AA$ A) in Bragg-Brentano geometry. Phase composition was determined by comparison to the Joint Committee of Powder Diffraction Standards (JCPDS) patterns. Crystallite size was calculated using the Scherrer equation, with a Scherrer constant value of 0.94 [39]. Average sizes were determined for each material using data from the (100), (002) and (101) reflections.

Single crystal X-Ray Diffraction. Crystals of 1 suitable for X-ray diffraction were obtained as described above. Data for $\mathbf{1}$ was collected at $100( \pm 2)^{\circ} \mathrm{K}$ on a Bruker APEX CCD diffractometer with Mo K radiation $(\lambda=0.71073 \AA)$ and a detector-to-crystal distance of 4.94 $\mathrm{cm}$. A full sphere of data was collected utilizing four sets of frames, 600 frames per set, with 
$0.5^{\circ}$ rotation about $\omega$ between frames and an exposure time of $10 \mathrm{~s}$ per frame. Data integration, correction for Lorentz and polarization effects, and final cell refinement were performed using SAINTPLUS and corrected for absorption using SADABS. The structure of $\mathbf{1}$ was solved using direct methods followed by successive least-squares refinement on $F^{2}$ using the SHELXTL 5.12 software package [40]. All non-hydrogen atoms were refined anisotropically, and hydrogen atoms were placed on the appropriate carbon atoms using the standard riding model. Relevant crystallographic data and data collection parameters are summarized in Table 1.

X-ray photoelectron spectroscopy. All ZnO samples were analyzed by X-ray photoelectron spectroscopy using a Physical Electronics Versaprobe system equipped with a 100 W monochromated Al Ka X-ray source. Samples were pressed into indium foil and secured under a molybdenum mask. Sample charging was minimized using low energy electrons and Ar ions, and spectra were shifted and charge referenced to the $\mathrm{C} 1 \mathrm{~s}$ peak at $284.8 \mathrm{eV}$. Samples were sputter cleaned using a $4 \mathrm{kV}, 5 \mu \mathrm{A}$ Ar ion beam rastered over a $2 \times 2 \mathrm{~mm}$ area for 1 minute at an Ar pressure of $\sim 5 \times 10^{-6} \mathrm{~Pa}$.

Scanning Electron Microscope. All $\mathrm{ZnO}$ products were characterized by field emission scanning electron microscopy (FESEM) (Hitachi, S-4500) to determine size and morphology. Quartz PCI Version 8 image processing software was used to acquire SEM micrographs. Accelerating voltage was varied from $7 \mathrm{kV}$ to $20 \mathrm{kV}$ depending on the sample requirements. Magnification ranged from $1,000 X$ to $200,000 X$. Particulate size of each powder dictated the magnification necessary to distinguish morphology. Outgassing was avoided in the FESEM vacuum chamber via a specific sample preparation. A diamond scribe was used to mark through the oxide layer on the sample stage. To secure the sample onto the sample stage and to avoid sample charging, a colloidal solution of Pelco silver paint was applied to the sample stage and 
allowed to air dry. A second coat of silver was applied to the sample stage, and the $\mathrm{ZnO}$ powder was deposited onto the wet silver paint. The paint was again allowed to dry. Immediately before inserting the mounted sample into the chamber, the sample spayed with compressed air to remove any loose particulates.

Conductivity type measurements. Conductivity type measurements were performed on the $\mathrm{ZnO}$ thin films by the rectifying three-point probe method [41, 42], using an Agilent 4156C Precision Semiconductor Parameter Analyzer using three of the four available source measurement units ( $2 \mu \mathrm{V}$ and 1 fA resolution), an Agilent E5250A Low Leakage Solid State Switch Matrix, and three DCM-210-M micromanipulators with tungsten probe tips connecting the devices enclosed in a Faraday cage to minimize electromagnetic noise. In the rectifying three-point probe technique, three tungsten probes were placed in parallel and approximately equidistant from each other (several millimeters apart) from left to right onto the $\mathrm{ZnO}$ film forming a metal-semiconductor contact (figure 1a). A bias, $V_{b}$, was applied to probe 1 while probe 2 was kept at ground, and the output voltage was measured at probe 3 relative to probe 2 (figure $1 \mathrm{a} \& \mathrm{~b}$ ). In theory, by biasing the metal-semiconductor contact over both negative and positive voltages, the rectification behavior of metal-semiconductor contacts will reveal the conductivity type. If $V_{32}$ value is close to a positive $V_{b}$ when $V_{b}$ is swept positively and $V_{32}$ is zero volts (ground) when $V_{b}$ is swept negatively, the semiconductor is n-type (figure 1c). Conversely, if $V_{32}$ is proximate to a negative $V_{b}$, when $V_{b}$ is biased in the negative direction and $V_{32}$ is measured to be zero volts when $V_{b}$ is biased positively, then the semiconductor is p-type (figure 1c). Finally, if $V_{32}$ is near the value of positive $V_{b}$ when $V_{b}$ is biased positively, and $V_{32}$ is near the value of negative $V_{b}$ when $V_{b}$ is biased negatively suggests the semiconductor is intrinsic-like. The rectifying three-point probe method was carried out on both n-type and p-type Si wafers to verify the technique, and the outcome is shown in figure 1c. For the $\mathrm{ZnO}$ thin films, 
$V_{b}$ was swept from $-4 \mathrm{~V}$ to $4 \mathrm{~V}$ while $V_{32}$ was measured. Since the three-point probe technique assumes rectifying (i.e., Schottky) contacts, energy band diagram simulations of the metalsemiconductor contacts were performed to examine the validity of the results.

[Figure 1 - Probe Technique here]

Figure 1. The rectifying three-point probe technique. $a$. Three tungsten probes in which $V_{b}$ is applied at probe 1 and current is measured at probe 2 while $V_{32}$ is measured at probe 3 . $b$. The circuit representation of the configuration shown in $a$. $c$. The applied bias, $\mathrm{V}_{\mathrm{b}}$, versus measured bias at probe 3 relative to probe $2, \mathrm{~V}_{32}$, showing the expected behavior for $\mathrm{n}$-type and p-type semiconductors and data for n-type $\mathrm{Si}$ and p-type Si. Adapted from references [41, 42].

\section{Results and Discussion}

Several $\left[\mathrm{Zn}(\text { acetate })_{2}(\operatorname{amine})_{\mathrm{x}}\right](\mathrm{x}=1$ or 2$)$ compounds were prepared, and their stoichiometries and compositions were confirmed by NMR and elemental analysis. Compound $\mathbf{1},\left[\mathrm{Zn}(\operatorname{acetate})_{2}(\mathrm{en})\right]$, was obtained from a stoichiometric reaction of zinc acetate dihydrate with ethylenediamine in ultrapure water, followed by crystallization from ethanol. When the reaction was performed with excess ethylenediamine in anhydrous ethanol and dried at $100^{\circ} \mathrm{C}$ in a flow of nitrogen, saturated with ethylenediamine, a compound with the stoichiometry of $\left[\mathrm{Zn}(\text { acetate })_{2}(\mathrm{en})_{2}\right](\mathbf{2})$ was obtained, as determined by ${ }^{1} \mathrm{H}$ NMR and elemental analysis. Although attempts were not made to obtain a single crystal X-ray structure of the second compound, NMR results are consistent with an octahedral coordination for the zinc and the acetate ligands bound trans to each other. The crystalline structure of $\left[\mathrm{Zn}(\text { acetate })_{2}(\mathrm{en})\right](\mathbf{1})$ was determined by single crystal X-ray diffraction. The unit cell of $\mathbf{1}$ contains four molecules, with the molecules stacking in layers normal to the (101) plane. The $\left[\mathrm{Zn}(\text { acetate })_{2}(\mathrm{en})\right]$ molecule 
(figure 2) shows the tetrahedral geometry expected for the $d^{10}$ zinc-containing precursor. The $\mathrm{Zn} 1-\mathrm{N}$ bond distance is $2.0739(13) \AA$, and the $\mathrm{N} 1-\mathrm{Zn} 1-\mathrm{N} 1 \mathrm{~A}$ angle is $85.57(8)^{\circ}$. This angle is less than the ideal $109.2^{\circ}$ angle of tetrahedral geometry due to the geometry of the ethylenediamine molecule, which does not allow the nitrogen atoms to separate to ideal tetrahedral configuration. The restricted N1-Zn1-N1A angle allows the O1-Zn1-O1A bonds to spread to an angle of $126.09(7)^{\circ}$. The Zn-O bonds to the acetates are 1.9714(12) $\AA$. All bond lengths and angles correlate well to values reported for similar compounds (Table 2) [43-46].

[Table 1 - STRUCTURAL Data Here]

Table 1. Crystal data and Structure refinement for [Zn(acetate $)_{2}$ en] 1.

\begin{tabular}{ll}
\hline Empirical formula & $\mathrm{C}_{6} \mathrm{H}_{14} \mathrm{~N}_{2} \mathrm{O}_{4} \mathrm{Zn}$ \\
Formula weight & 243.56 \\
$T(\mathrm{~K})$ & $100(2)$ \\
$l(\AA)$ & 0.71073 \\
Crystal system & Orthorhombic \\
Space group & Pbcn \\
$a(\AA)$ & $12.2486(13)$ \\
$b(\AA)$ & $7.7063(8)$ \\
$c(\AA)$ & $10.1889(11)$ \\
$\alpha(\mathrm{deg})$ & 90 \\
$\beta(\mathrm{deg})$ & 90 \\
$\gamma(\mathrm{deg})$ & 90 \\
$\mathrm{~V}\left(\AA^{3}\right)$ & $961.74(18)$ \\
$Z$ & 4 \\
$D_{\text {calc }}\left(\mathrm{Mg} / \mathrm{m}^{3}\right)$ & 1.682 \\
abs coeff $\left(\mathrm{mm}^{-1}\right)$ & 2.540 \\
cryst size $\left(\mathrm{mm}^{3}\right)$ & $0.28 \times 0.16 \times 0.04$ \\
$\theta$ range for data collection $(\mathrm{deg})$ & $3.12-32.27$ \\
Index ranges & $-18 \leq h \leq 18$, \\
\hline
\end{tabular}




\begin{tabular}{ll}
\hline & $-11 \leq k \leq 11$, \\
& $-14 \leq l \leq 15$ \\
reflns collected & 10708 \\
indep reflns & 1697 \\
& {$\left[R_{\text {int }}=0.0364\right]$} \\
abs correction & SADABS \\
Data / restraints / parameters & $1697 / 0 / 88$ \\
GOF $F^{2}$ & 1.068 \\
Final $R$ indices & $R_{1}=0.0293$, \\
{$[I>2 \sigma(I)]$} & $R_{2}=0.0705$ \\
R indices & $R_{1}=0.0432$, \\
(all data) & $R_{2}=0.0773$ \\
CCDC no. & 972792 \\
\hline
\end{tabular}

Figure 2. Thermal ellipsoid diagram of [Zn(acetate) ${ }_{2}$ (ethylenediamine)] (1). Atoms are represented by ellipsoids at $50 \%$ probability.

[Figure 2 - Structure here]

[Table 2 - Bond Lengths and Angles Here]

Table 2. Selected bond lengths $(\AA)$ and bond angles (degrees) for $\mathbf{1}$.

\begin{tabular}{lllc}
\hline Bond & Bond Length, $\AA$ & Bond & Bond Angle, $^{\circ}$ \\
\hline Zn-O(1) & $1.9714(12)$ & $\mathrm{O}(1)-\mathrm{Zn}-\mathrm{O}(1 \mathrm{~A})$ & $126.09(7)$ \\
$\mathrm{Zn}-\mathrm{N}(1)$ & $2.0739(13)$ & $\mathrm{N}(1)-\mathrm{Zn}-\mathrm{N}(1 \mathrm{~A})$ & $85.57(8)$ \\
& & $\mathrm{O}(1)-\mathrm{Zn}-\mathrm{N}(1)$ & $107.45(5)$ \\
& & $\mathrm{O}(1)-\mathrm{Zn}-\mathrm{N}(1 \mathrm{~A})$ & $111.43(5)$ \\
\hline
\end{tabular}

The thermal properties of compounds 1-6 were probed using thermogravimetric analysis/differential scanning calorimetry - mass spectroscopy (TGA/DSC-MS) in both air and argon atmospheres. When heated in air, the precursors thermally decompose in multiple steps to 
yield $\mathrm{ZnO}$ (Figure 3). The temperature of $\mathrm{ZnO}$ formation varies with the amine bound to the zinc acetate (Table 3), with benzylamine and ammonia yielding the lowest formation temperatures and tris producing the highest. The high $\mathrm{ZnO}$ formation temperature of $\left[\mathrm{Zn}(\text { acetate })_{2}(\operatorname{tris})_{2}\right]$ is attributed to tris being the least volatile of the monodentate amines with a boiling point of $220^{\circ} \mathrm{C}$, and the tris molecule thermally cracking rather than vaporizing intact, as determined by TGA-MS (Figure SI-1). The temperature for $\mathrm{ZnO}$ formation using $\left[\mathrm{Zn}(\text { acetate })_{2}(\text { benzylamine })_{2}\right]$ is slightly lower than that observed for the oxidation $\mathrm{Zn}$ (acetate) $)_{2} \cdot 2 \mathrm{H}_{2} \mathrm{O}$ to $\mathrm{ZnO}$, which occurs at $350^{\circ} \mathrm{C}$. Therefore, by choosing different amines, the $\mathrm{ZnO}$ formation temperature may be tuned from 335 $-590^{\circ} \mathrm{C}$. When heated in an argon atmosphere, the compounds containing benzylamine, ammonia and butylamine have $\mathrm{ZnO}$ formation temperature similar to that observed in air, but the final weight loss step for the tris- and ethylenediamine-containing precursors extends over several hundred degrees (Figure 4).

Figure 3. Thermogravimetric analysis (TGA) curves for the heating of the six chemical precursor to $1000^{\circ} \mathrm{C}$ in dry air at a rate of $20^{\circ} \mathrm{C} / \mathrm{min}$. The figure illustrates how the amine bound to the zinc affects the $\mathrm{ZnO}$ formation temperature.

Figure 4. Thermogravimetric analysis (TGA) curves for the heating of the six chemical precursor to $1000^{\circ} \mathrm{C}$ in argon at a rate of $20^{\circ} \mathrm{C} / \mathrm{min}$.

[Figures $3 \& 4$ here - TGAs]

[Table 3 here] 
Table 3. Thermal data for $\left[\mathrm{Zn}(\text { acetate })_{2}(\text { amine })_{\mathrm{x}}\right]$ compounds pyrolyzed in dry air.

\begin{tabular}{lcc}
\hline Precursor compound & ZnO Formation Temp. & Residue (\%) \\
\hline $\mathrm{Zn}(\text { acetate })_{2}(\mathrm{en})$ & $530^{\circ} \mathrm{C}$ & 34.10 \\
$\mathrm{Zn}(\text { acetate })_{2}(\mathrm{en})_{2}$ & $530^{\circ} \mathrm{C}$ & 26.03 \\
$\mathrm{Zn}(\text { acetate })_{2}$ (tris $)_{2}$ & $590^{\circ} \mathrm{C}$ & 19.14 \\
$\mathrm{Zn}(\text { acetate })_{2}(\text { benzylamine })_{2}$ & $335^{\circ} \mathrm{C}$ & 17.58 \\
$\mathrm{Zn}(\text { acetate })_{2}(\text { butylamine })_{2}$ & $350^{\circ} \mathrm{C}$ & 24.94 \\
$\mathrm{Zn}(\text { acetate })_{2}\left(\mathrm{NH}_{3}\right)_{2}$ & $355^{\circ} \mathrm{C}$ & 35.01 \\
\hline
\end{tabular}

Using the TGA data as a guide, larger quantities of each of the precursors were pyrolyzed in nitrogen and air, and the products were characterized by powder X-ray diffraction (XRD) and scanning electron microscopy. All the precursors pyrolyzed in air were white in color, whereas precursors pyrolyzed under an inert atmosphere were all dark gray to black due to carbon incorporation. All the pyrolyzed samples yielded wurtzite $\mathrm{ZnO}$, as determined by powder $\mathrm{X}$-ray diffraction (JCPDS 00-036-1451) (figures $5 \& 6$ ), and were generally very crystalline. The exception was $\left[\mathrm{Zn}(\text { acetate })_{2}(\text { tris })_{2}\right]$, which yielded a material with lower crystallinity or smaller crystallite size when pyrolyzed under inert conditions. This result is consistent with the weight loss observed in the TGA for this compound, which extends well above the $650^{\circ} \mathrm{C}$ pyrolysis temperature. Average crystallite sizes for the pyrolyzed materials were calculated using the Sherrer equation [39]. Average crystallite sizes were determined to be $40 \mathrm{~nm}, 48 \mathrm{~nm}, 43 \mathrm{~nm}, 40$ $\mathrm{nm}, 38 \mathrm{~nm}$ and $40 \mathrm{~nm}$ for material from [Zn(acetate $\left.)_{2}(\operatorname{tris})_{2}\right],\left[\mathrm{Zn}(\text { acetate })_{2}(\mathrm{en})\right]$, $\left[\mathrm{Zn}(\text { acetate })_{2}(\mathrm{en})_{2}\right],\left[\mathrm{Zn}(\text { acetate })_{2}(\text { butylamine })_{2}\right],\left[\mathrm{Zn}(\text { acetate })_{2}\left(\mathrm{NH}_{3}\right)_{2}\right]$, and $\left[\mathrm{Zn}(\text { acetate })_{2}(\text { benzylamine })_{2}\right]$, respectively when pyrolyzed in air and $7 \mathrm{~nm}, 38 \mathrm{~nm}, 43 \mathrm{~nm}, 31$ $\mathrm{nm}, 36 \mathrm{~nm}$ and $38 \mathrm{~nm}$, respectively when pyrolyzed in nitrogen.

[Figure 5 - XRD All precursors pyrolyzed in air] 
Figure 5. Powder X-ray diffraction data for the products obtained from the pyrolysis of compounds $1-6$ in air.

[Figure 6 - XRD All precursors pyrolyzed in $\mathrm{N}_{2} / \mathrm{Ar}$ ]

Figure 6. Powder X-ray diffraction data for the products obtained from the pyrolysis of compounds 1-6 in an inert atmosphere.

The pyrolyzed materials were characterized by field emission scanning electron microscopy to explore the effect of the different amines on crystal morphology and size (Figures 7 and 8). All of the materials heated in air have a sintered/melted appearance. With the exception of the benzyl- and butyl containing precursors, the products have poorly defined morphology and vary in size from $75-200 \mathrm{~nm}$ for [Zn(acetate) $)_{2}(\text { tris })_{2}$ ], from $100-300 \mathrm{~nm}$ for $\left[\mathrm{Zn}(\text { acetate })_{2}\left(\mathrm{NH}_{3}\right)_{2}\right]$ and from $120-360 \mathrm{~nm}$ for $\left[\mathrm{Zn}(\text { acetate })_{2}(\mathrm{en})_{2}\right]$. The material obtained from the pyrolysis of $\left[\mathrm{Zn}(\text { acetate })_{2}(\mathrm{en})\right]$ form aggregates with sizes ranging up to $1.2 \mu \mathrm{m}$ and with grain sizes as small as $100 \mathrm{~nm}$. In contrast, the benzyl- and butyl containing precursors yield products with rod-shaped morphology. The rods produced from [ $\left.\mathrm{Zn}(\text { acetate })_{2}(\text { benzylamine })_{2}\right]$ have a $90 \mathrm{~nm}$ cross section and range in length from $300-500 \mathrm{~nm}$, whereas the rod produced using $\left.\left[\mathrm{Zn}(\text { acetate })_{2} \text { (butylamine }\right)_{2}\right]$ have a similar cross section but with lengths ranging up to 600 nm.

[Figure 7 - SEM all precursors pyrolyzed in Air] 
Figure 7. Field emission scanning electron microscopy images obtained from the pyrolysis of compounds 1-6 in dry air. The number on the image corresponds to the compound used to produce the material.

When pyrolyzed under inert conditions all of the precursors, except [ $\left.\mathrm{Zn}(\text { acetate })_{2}(\operatorname{tris})_{2}\right]$ and $\left[\mathrm{Zn}(\text { acetate })_{2}\left(\mathrm{NH}_{3}\right)_{2}\right]$, yielded well defined rod-shaped crystals. The benzyl- and butylcontaining precursors produced the smallest diameter rods of $60 \mathrm{~nm}$ and lengths ranging from $160-450 \mathrm{~nm}$ for the benzyl precursor and 350-650 $\mathrm{nm}$ for butyl-containing precursor. The two ethylenediamine-containing precursors produced rods with approximately $100 \mathrm{~nm}$ diameters and lengths ranging from $240-480 \mathrm{~nm}$ for 1 and $180-750 \mathrm{~nm}$ for $\mathbf{2}$. The [Zn(acetate $)_{2}\left(\mathrm{NH}_{3}\right)_{2}$ ] precursor yielded poorly defined crystals with diameters of approximately $80 \mathrm{~nm}$. The $\left[\mathrm{Zn}(\text { acetate })_{2}(\text { tris })_{2}\right]$ precursor produced aggregated crystals with $50 \mathrm{~nm}$ grain size. Therefore, the different amines bound to the zinc influence both the size and morphology of the $\mathrm{ZnO}$ produced by pyrolysis of compounds $1-6$.

[Figure 8 - SEM all precursors pyrolyzed in inert atmosphere]

Figure 8. Field emission scanning electron microscopy images obtained from the pyrolysis of compounds 1-6 in an inert atmosphere.

Precursors 1 and 3-6 were also used to prepare bulk powders of $\mathrm{ZnO}$ by alkali precipitation. The $\mathrm{ZnO}$ was precipitated from aqueous solutions at a $\mathrm{pH}=10$ by the addition of 
$\mathrm{NaOH}$. The precipitation was carried out at $65^{\circ} \mathrm{C}$ and $75^{\circ} \mathrm{C}$ and the time for precipitation titration was varied from 5 minutes to 30 minutes. All precipitations yielded wurtzite $\mathrm{ZnO}$, as determined by powder X-ray diffraction (figure 9). Average crystallite size for the materials characterized in figure 9 were calculated using the Sherrer equation to be $33 \mathrm{~nm}, 43 \mathrm{~nm}, 35 \mathrm{~nm}$, $40 \mathrm{~nm}$, and $35 \mathrm{~nm}$ for material from [Zn(acetate $\left.)_{2}(\operatorname{tris})_{2}\right]$, [Zn(acetate $\left.)_{2}(\mathrm{en})\right]$, [Zn(acetate $)_{2}$ (butylamine $\left.)_{2}\right],\left[\mathrm{Zn}(\text { acetate })_{2}\left(\mathrm{NH}_{3}\right)_{2}\right]$, and [ $\mathrm{Zn}(\text { acetate })_{2}$ (benzylamine $\left.)_{2}\right]$, respectively. Temperature, rate of precipitation and the amine bound to the zinc were all found to have a pronounced effect on the morphology and particle size of the material produced. Consistent with the Ostwald ripening mechanism, higher temperatures and slower precipitation rates yielded larger particles for a given morphology [47], as has been observed using other $\mathrm{ZnO}$ precursors [33]. The amine bound to the zinc was found to direct the morphology of the particles, with ethylenediamine yielding needles, tris producing plates, benzylamine and butylamines yielding short needles, and $\mathrm{NH}_{3}$ producing hexagonal rods. The benzylamine and butylamine products often resembled grains of rice. The materials produced using tris were either well defined hexagonal plates or as shown in figure 10, plates with rounded edges. Scanning electron micrographs of the materials obtained at $75^{\circ} \mathrm{C}$ and precipitated over 30 minutes are provided in figure 10. Garcia has shown that the denticity of carboxylate ligands in solution during $\mathrm{ZnO}$ crystal growth has a pronounced impact on the crystal aspect ratio, with monodentate ligands yielding rods, tridentate ligands producing plates, and bidentate ligands yielding intermediate short rods [35]. The use of monodentate and bidentate amines to control crystal aspect ratio in this work, suggests that the effects of denticity on crystal aspect ratio is more complex than previously understood.

[Figure 9 - powder XRD of alkali precipitation $\mathrm{ZnO}$ powders] 
Figure 9. Powder X-ray diffraction data for $\mathrm{ZnO}$ powders obtained by alkali precipitation of the different precursors at $75^{\circ} \mathrm{C}$. Sodium hydroxide was added over the course of 25-30 minutes to precipitate the products. All products were annealed at $200^{\circ} \mathrm{C}$ for two hours in a nitrogen atmosphere.

[Figure $10-\mathrm{SEM}$ alkali precipitation at $75^{\circ} \mathrm{C}$ ]

Figure 10. Field emission scanning electron microscopy images of $\mathrm{ZnO}$ obtained from the alkali precipitation over the course of 30 minutes at $75^{\circ} \mathrm{C}$ for compounds 1 and 3-6. All samples were annealed at $200^{\circ} \mathrm{C}$ for two hours under nitrogen.

A primary goal of this work was to explore the use of these compounds to prepare bulk quantities of nitrogen-doped $\mathrm{ZnO}$ powders. Zinc oxide powders obtained by precipitation were characterized by XPS. All of the materials contained minimal nitrogen, with percent nitrogen concentrations ranging from $0.3-0.5 \%$ for $\mathrm{ZnO}$ prepared from the precursors containing $\mathrm{NH}_{3}$, butylamine, and ethylenediamine to $1.1-1.6 \%$ for benzylamine and tris. X-ray photoelectron spectroscopy analysis is provided in the supporting information (Figures SI-2 and SI-3 and Table SI-1). The observed nitrogen content is consistent with the t-butyl group of the tris molecule and the benzyl group being more stable leaving groups, yielding $\mathrm{ZnO}$ with higher nitrogen doping. Although the amine bound to the precursor does affect nitrogen concentrations in the resulting $\mathrm{ZnO}$, these nitrogen concentration levels are not expected to produce p-type $\mathrm{ZnO}$ [48, 49]. 
To further investigate the usefulness of these precursors, they were used to deposit thin films of $\mathrm{ZnO}$ in air by spray pyrolysis. Methanol solutions of each precursor were sprayed onto pyrex substrates, with the substrate temperature held at $550^{\circ} \mathrm{C}$. Both air and argon were used as the carrier gas, but argon was found to yield higher quality films. Precursors [Zn(acetate) 2 (en)], $\left[\mathrm{Zn}(\text { acetate })_{2}(\text { butylamine })_{2}\right]$, and $\left[\mathrm{Zn}(\text { acetate })_{2}\left(\mathrm{NH}_{3}\right)_{2}\right]$ yielded high quality, well adhered, optically transparent films (Figure SI-4). The precursor $\left[\mathrm{Zn}(\text { acetate })_{2}(\text { tris })_{2}\right]$ yielded powdery, optically opaque films. This result is consistent with the TGA data, which gives the thermal decomposition of $\left.\left[\mathrm{Zn}(\text { acetate })_{2} \text { (tris }\right)_{2}\right]$ at or above the substrate temperature. The compound $\left.\left[\mathrm{Zn}(\text { acetate })_{2} \text { (benzylamine }\right)_{2}\right]$ yielded very thin films contaminated with partially decomposed precursor, as they contained high concentrations of both carbon and nitrogen, as determined by XPS. All of the precursors yielded wurtzite $\mathrm{ZnO}$ films, with a (100) preferred growth orientation (figure 11). The amorphous broad low intensity peak in Figure 11 is attributed to the glass substrate, as the film had an average thickness of $1.1 \mu \mathrm{m}$. Sherrer equation calculations give an average crystallite size of $24 \mathrm{~nm}$ for the film used for Figure 11. The films were characterized by XPS, but again the high quality films revealed minimal nitrogen incorporation, likely from the formation of volatile nitrogen oxide compounds during precursor decomposition. The optical energy band gap, as measured by optical transmission, varied from $3.29 \mathrm{eV}$ to $3.32 \mathrm{eV}$, similar to the reported value of $3.37 \mathrm{eV}$ [50]. Lower measured optical band gaps are possibly due to increased scattering from the high surface roughness of the films.

[Figure 11 - X-ray diffraction of thin film] 
Figure 11. X-ray powder diffraction of a $\mathrm{ZnO}$ thin film grown using $\left[\mathrm{Zn}(\text { acetate })_{2}\left(\mathrm{NH}_{3}\right)_{2}\right]$.

Conductivity type measurements using the rectifying three-point probe method (Figure 1) revealed that n-type to somewhat intrinsic type conductivity was prevalent in all samples, consistent with intrinsic $\mathrm{ZnO}$, with the films having varying degrees of conductivity.

Representative data revealing the conductivity type behavior of the $\mathrm{ZnO}$ thin films are shown in Figure 12. Theoretically, if $V_{32}$ follows the value of $V_{b}$ in a one-to-one ratio as $V_{b}$ is swept positively and $V_{32}$ is at ground (i.e., $0 \mathrm{~V}$ ) as $V_{b}$ is swept negatively, then the semiconductor is ntype. Alternatively, if $V_{32}$ follows the value of $V_{b}$ in a one-to-one ratio as $V_{b}$ is swept negatively, and $V_{32}$ is at ground as $V_{b}$ is swept positively, then the semiconductor is p-type. However, it is apparent that the results are not so well defined. The conductivity results of the $\mathrm{ZnO}$ thin films seem to fall into three regimes of $V_{32}$. Hence, the criteria of $V_{32}$ values in ratios of $V_{b}$ were developed and applied as outlined in Table 4. Based on these criteria, the conductivity type results of the $\mathrm{ZnO}$ thin films were organized into 3 categories: n-type behavior, moderate n-type behavior, and intrinsic-like behavior (Table 4). As seen in Table 4, most of the samples were observed to exhibit moderately n-type, with $\left[\mathrm{Zn}(\text { acetate })_{2}(\text { butylamine })_{2}\right]$ and $\left[\mathrm{Zn}(\text { acetate })_{2}(\mathrm{en})\right]$ yielding n-type to moderately n-type films and $\left[\mathrm{Zn}(\text { acetate })_{2}\left(\mathrm{NH}_{3}\right)_{2}\right]$ producing films of moderately n-type to intrinsic behavior. Films prepared from [ $\left.\mathrm{Zn}(\text { acetate })_{2}\right]$ solutions, with no added amine also revealed moderately n-type behavior. The criteria may appear somewhat subjective, but what is clear from the results is that $\mathrm{p}$-type behavior in the $\mathrm{ZnO}$ thin films is not observed.

[Figure 12 - Conductivity Measurements] 
Figure 12. Representative conductivity type measurement data from several $\mathrm{ZnO}$ thin films - two films exhibit n-type behavior, two exhibit moderate n-type while one shows intrinsic-like behavior. Theoretical lines for n-type and p-type semiconductor are included to help guide the reader.

[Table 4 - Conductivity Type]

TABLE 4: Precursor, conductivity type, and criteria to determine conductivity type of $\mathrm{ZnO}$ thin film samples.

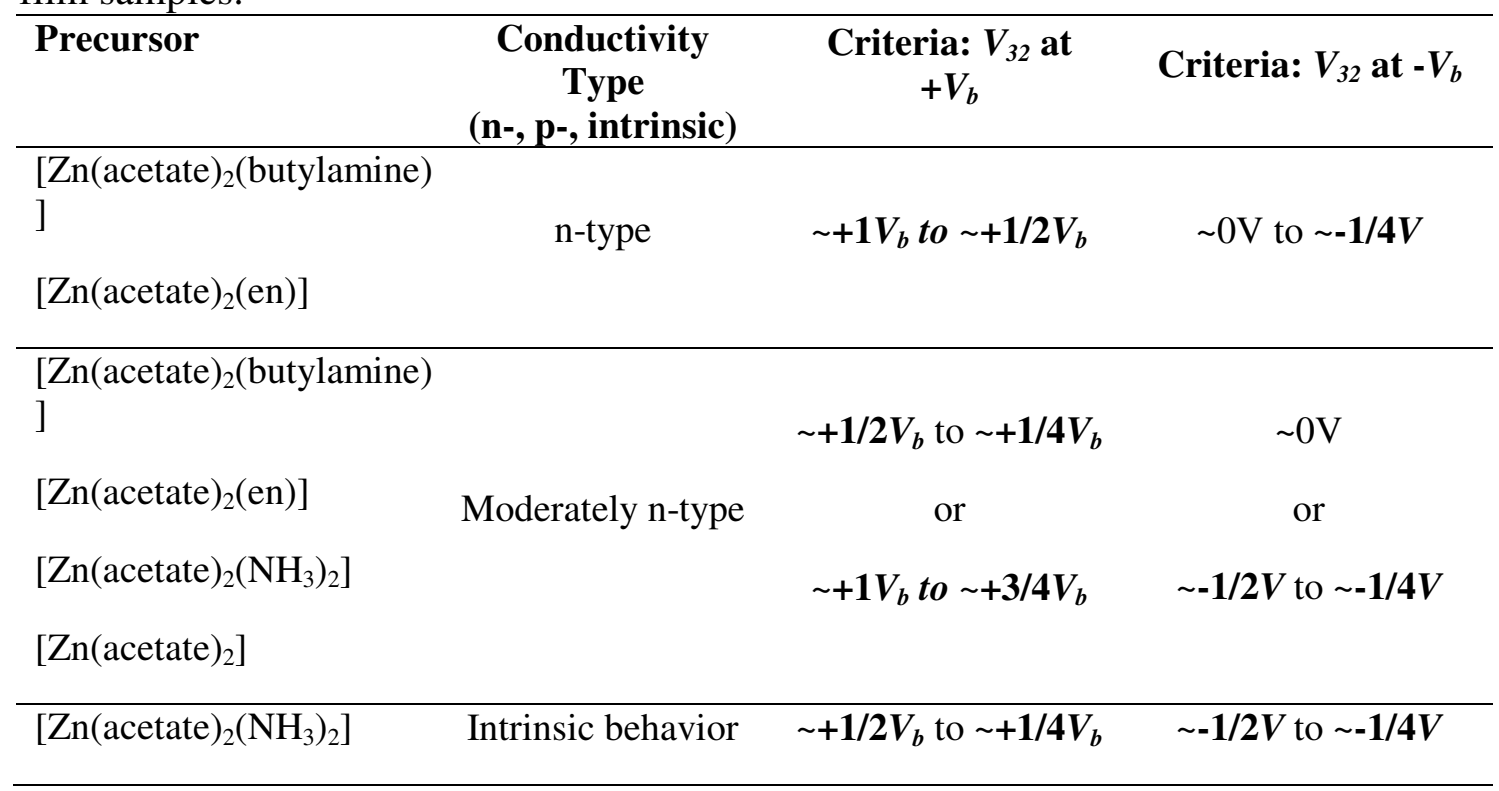

Energy band diagram simulations were performed using the energy band diagram simulation tool established at Boise State University $[51,52]$. The simulations require an intrinsic material between the semiconductor and the metal. It is reasonable to assume this scenario since intrinsic behavior of semiconductor surfaces can be induced by the presence of surface states or native oxides. Thus, very thin $(0.5 \mathrm{~nm})$ intrinsic native oxides were incorporated in simulating both the $\mathrm{W}-\mathrm{ZnO}$ and the $\mathrm{W}-\mathrm{Si}$ contacts. Assuming the intrinsic thin native oxides used in the simulations are to first order charge-free, their presence do not affect the outcome because the work function differences (i.e., built-in voltage) are dictated by the work function (i.e., Fermi energy) differences between only the metal and the doped semiconductor. The materials parameters used for the simulations are listed in Table 5. A tungsten thickness of $5 \mathrm{~nm}$ 
was chosen for maximize energy band diagram visualization and has no bearing on its work function, $\varphi_{\mathrm{w}}$. The doping concentration of all semiconductors, $2 \times 10^{18} \mathrm{~cm}^{-3}$, was kept constant to minimize ambiguities for comparisons between tungsten contacts to $\mathrm{ZnO}$ and silicon. The high doping concentration was chosen because $\mathrm{ZnO} n_{i}\left(1 \times 10^{16} \mathrm{~cm}^{-3}\right)$ [53] is so large considering the energy band gap $\left(E_{g}\right)$ for $\mathrm{ZnO}$ is a relatively large $\sim 3.44 \mathrm{eV}$. Typically, $n_{i}$ scales inversely to the semiconductor energy band gap (e.g. $n_{i}$ : GaAs $\sim 10^{6} \mathrm{~cm}^{-3}$, Si $\sim 10^{10} \mathrm{~cm}^{-3}$, Ge $\sim 10^{13} \mathrm{~cm}^{-3}$; $E_{g}$ : GaAs $\sim 1.42 \mathrm{eV}, \mathrm{Si} \sim 1.12 \mathrm{eV}, \mathrm{Ge} \sim 0.66 \mathrm{eV})[51,52]$. The large $n_{i, \mathrm{ZnO}}$ is owed to its high defect density [53]. For simulation purposes due to the limitations of the energy band diagram program, the doping concentration needs to be $\sim 200$ times greater than $n_{i}$. The high doping concentration is consistent with recently reported p-type nitrogen-doped $\mathrm{ZnO}$ with carrier densities ranging from $10^{19}$ to $10^{23} \mathrm{~cm}^{-3}[54]$.

[Table 5 - Materials Parameters]

Table 5: Materials and materials parameters at $300 \mathrm{~K}$ used for the energy band diagram simulations.

\begin{tabular}{ccccccc}
\hline MaterialIParameters & $\begin{array}{c}\text { Work } \\
\text { Function, } \\
\varphi(\mathbf{e V})\end{array}$ & $\begin{array}{c}\text { Electron } \\
\text { Affinity, } \chi \\
(\mathbf{e V})\end{array}$ & $\begin{array}{c}\text { Band } \\
\text { Gap } \\
\text { Energy, } \\
\boldsymbol{E}_{g}(\mathbf{e V})\end{array}$ & $\begin{array}{c}\text { Intrinsic Carrier } \\
\text { Concentration, } \\
\left(\mathbf{c a r r i e r s} / \mathbf{c m}^{-3}\right)\end{array}$ & $\begin{array}{c}\text { Relative } \\
\text { Dielectric } \\
\text { Constant }\end{array}$ & Reference \\
\hline Tungsten, W & 4.5 & N/A & N/A & N/A & N/A & {$[51,52]$} \\
Silicon, $\mathrm{Si}$ & $*$ & 4.05 & 1.125 & $1.41 \times 10^{10}$ & 11.7 & {$[51,52]$} \\
Zinc Oxide, $\mathrm{ZnO}$ & $*$ & 4.6 & 3.44 & $1 \times 10^{16}$ & 8.75 & {$[51-53]$}
\end{tabular}

*: Depends on whether n-type or p-type

The primary difference between $\mathrm{W}-\mathrm{Si}$ and $\mathrm{W}-\mathrm{ZnO}$ contacts is that tungsten contacts to $\mathrm{p}$ $\mathrm{Si}, \mathrm{n}-\mathrm{Si}$ and $\mathrm{p}-\mathrm{ZnO}$ are Schottky, but the tungsten contact on $\mathrm{n}-\mathrm{ZnO}$ is ohmic. The reason is twofold. The primary reason is attributed to the sufficiently large electron affinity of $\mathrm{ZnO}\left(\chi_{\mathrm{ZnO}}\right.$ 
$\sim 4.6 \mathrm{eV})$ where $\varphi_{\mathrm{w}}$ is less than $\chi_{\mathrm{ZnO}}$. Not as significant as the first reason but nonetheless impactful is the large value of $n_{i, Z n O}-$ it is so large for a rather large energy band gap semiconductor as compared to $n_{i, S i}$ (Table 5) that the Fermi energies of both p- and n-type $\mathrm{ZnO}$ (i.e., $E_{f, p}$ and $\left.E_{f, n}\right)$ are near the mid-energy band gap of $\mathrm{ZnO}\left(E_{i, Z n o}\right)$ and hence $E_{f, p}$ and $E_{f, n}$ will not differ significantly from one another. That is, $E_{f, p}, E_{f, n}$, and $E_{i, Z n O}$ are relatively similar. Hence, the tungsten- $\mathrm{ZnO}$ contact for $\mathrm{n}$-type is ohmic, whereas the $\mathrm{p}$-type $\mathrm{W}-\mathrm{ZnO}$ contact is Schottky (i.e., rectifying, blocking).

Will the W-nZnO ohmic contact significntly affect the electrical measurements? Since $e V_{B I, n Z n O}$ is small (table SI-3), the ohmic contact does not significantly affect biasing conditions. That is, the amount of voltage $\left(V_{b}\right)$ required to bend the $\mathrm{n}-\mathrm{ZnO}$ energy bands to the Schottky condition (reverse bias condition) is less than $2 \mathrm{~V}$. By examining the band bending in the $\mathrm{W}$ nZnO contact over the range of biasing conditions for $V_{b}$ (i.e., $-4 \mathrm{~V}$ to $4 \mathrm{~V}$ ) as shown in Figure SI5 , the band bending in $\mathrm{n}-\mathrm{ZnO}$ is very similar to that of $\mathrm{n}-\mathrm{Si}$ except at equilibrium conditions (i.e., $\left.V_{b}=0 \mathrm{~V}\right)$.

Overall, the simulations reveal interesting aspects, without which, are not immediately apparent. It can be seen that to obtain p-type conductivity in $\mathrm{ZnO}$ with such a high intrinsic carrier concentration, the concentration of nitrogen donors must be at least $10^{18} \mathrm{~cm}^{-3}$ in order to observe p-type behavior. However, at these concentrations, one needs to be concerned with the solubility limit of nitrogen in $\mathrm{ZnO}$.

\section{Closing Remarks}

The $\left[\mathrm{Zn}(\text { acetate })_{2}(\text { amine })_{\mathrm{x}}\right](\mathrm{x}=1$ or 2$)$ compounds prepared for this study may be used as single source precursors to $\mathrm{ZnO}$ bulk powders by alkali precipitation and to $\mathrm{ZnO}$ thin films by 
spray pyrolysis. The amine bound to the zinc during precipitation influences $\mathrm{ZnO}$ crystal size and shape and acts as a nitrogen donor to give nitrogen doped $\mathrm{ZnO}$. However, nitrogen doping was minimal, with the best amine (tris) only yielding $1.6 \%$ nitrogen incorporation. The six compounds investigated in this study were used because the solid form could be stored for extended periods and readily redissolved. Many other amines were examined and the products characterized by solution NMR, but the solid $\left[\mathrm{Zn}(\text { acetate })_{2}(\text { amine })_{2}\right]$ compounds would become insoluble in common solvents after a few days in air and some within a week when stored in a nitrogen filled glovebox. However, many of the $\left[\mathrm{Zn}(\text { acetate })_{2}(\text { amine })_{2}\right]$ compounds that were not storable in solid form were prepared in situ, and the solutions were used to generate $\mathrm{ZnO}$ bulk powders. All of the amines used were found to influence crystal size and shape. Our study of these materials will be reported elsewhere. Additionally, the authors note that amine selection does influence morphology by more complex pathways than previously reported [35]. Three of

the precursors were useful for preparing high quality, well adhering, optically transparent films of $\mathrm{ZnO}$ by spray pyrolysis. The films had n-type to somewhat intrinsic type conductivity. Films grown using $\left[\mathrm{Zn}(\text { acetate })_{2}\right.$ (tris) $]$ were powdery and opaque, and films prepared using $\left[\mathrm{Zn}(\text { acetate })_{2}(\text { benzylamine })_{2}\right]$ contained high concentrations of carbon and nitrogen. Films were also deposited using solutions of $\left[\mathrm{Zn}(\text { acetate })_{2}(\text { amine })_{2}\right]$ compounds generated in situ, as discussed above, and those results will also be reported elsewhere.

\section{Acknowledgment}

We gratefully acknowledge the financial support from the National Science Foundation through grants DMR 0722699, DMR 0840265, and CHE 0226402, support by an Institutional Development Award (IDeA) from the National Institute of General Medical Sciences of the 
National Institutes of Health under Grant \#P20GM103408, NASA Idaho Space Grant Consortium, M.J. Murdock Charitable Trust, and Northwest Nazarene University’s Science, Math Associates.

\section{Supporting Information Available}

A complete listing of anisotropic displacement parameters, interatomic distances, angles, hydrogen coordinates and displacement parameters for [1] are available upon request from the authors. CCDC 972792 also contains the supplementary crystallographic data for [1], and can be obtained free of charge from The Cambridge Crystallographic Data Centre via www.ccdc.cam.ac.uk/data_request/cif. Thermogravimetric analysis - mass spectrometry data for $\left[\mathrm{Zn}(\text { acetate })_{2}(\text { tris })_{2}\right]$ heated in argon, XPS analysis data for $\mathrm{ZnO}$ powders, a photo of representative thin films grown on pyrex substrates, tables of polarity and bias conditions for the rectifying three-point probe conductivity type method, a table of contact types, built-in voltages, and built-in voltage differences, as well as figures of energy band diagrams of $\mathrm{W} / \mathrm{iZnO} / \mathrm{ZnO}$ and $\mathrm{W} / \mathrm{iSiO}_{2} / \mathrm{Si}$ from the conductivity simulations are available in the supplemental material. 


\section{References:}

[1] A. Ennaoui, M. Weber, R. Scheer, H.J. Lewerenz, Sol. Energy Mater. Sol. Cells, 54 (1998) 277-286.

[2] J.B. Lee, H.J. Lee, S.H. Seo, J.S. Park, Thin Solid Films, 398-399 (2001) 641-646.

[3] F. Paraguay D., M. Miki-Yoshida, J. Morales, J. Solis, W. Estrada L., Thin Solid Films, 373 (2000) 137-140.

[4] R. Das, S. Ray, J. Phys. D Appl. Phys., 36 (2003) 152-155.

[5] K.M. Reddy, K. Feris, J. Bell, D.G. Wingett, C. Hanley, A. Punnoose, Applied Physics Letters, 90 (2007) 213902.

[6] S.A. Ansari, Q. Husain, S. Qayyum, A. Azam, Food Chem Toxicol, 49 (2011) 2107-2115.

[7] A. Thurber, D.G. Wingett, J.W. Rasmussen, J. Layne, L. Johnson, D.A. Tenne, J. Zhang, C.B. Hanna, A. Punnoose, Nanotoxicology, 6 (2012) 440-452.

[8] R. Velmurugan, M. Swaminathan, Sol. Energy Mater. Sol. Cells, 95 (2011) 942-950.

[9] J.O. Saucedo-Lucero, S. Arriaga, Chem. Eng. J., 218 (2013) 358-367.

[10] D.C. Look, D.C. Reynolds, C.W. Litton, R.L. Jones, D.B. Eason, G. Cantwell, Applied Physics Letters, 81 (2002) 1830-1832.

[11] D.C. Look, D.C. Reynolds, J.W. Hemsky, R.L. Jones, J.R. Sizelove, Applied Physics Letters, 75 (1999) 811-813.

[12] T. Dietl, H. Ohno, F. Matsukura, J. Cibert, D. Ferrand, Science, 287 (2000) 1019-1022.

[13] H. Ohno, Science, 281 (1998) 951-956.

[14] B. Claflin, D.C. Look, S.J. Park, G. Cantwell, J. Cryst. Growth, 287 (2006) 16-22.

[15] H.Y. Xu, Y.C. Liu, C.S. Xu, Y.X. Liu, C.L. Shao, R. Mu, Applied Physics Letters, 24 (2006) 242502-242502-242503.

[16] J.P. Zhang, L.D. Zhang, L.Q. Zhu, Y. Zhang, M. Liu, X.J. Wang, G. He, J. Appl. Phys., 102 (2007) 114903.

[17] N. Tabet, M. Faiza, A. Al-Oteibi, J. Electron. Spectrosc. Relat. Phenom., 163 (2008) 1518.

[18] M. Hirai, A. Kumar, J. Vac. Sci. Technol. A, 25 (2007) 1534-1538.

[19] K. Iwata, H. Tampo, A. Yamada, P. Fons, K. Matsubara, K. Sakurai, S. Ishizuka, S. Niki, Appl. Surf. Sci., 244 (2005) 504-510.

[20] C.L. Perkins, S.-H. Lee, X. Li, S.E. Asher, T.J. Coutts, J. Appl. Phys., 97 (2005) 034907. 
[21] Y. Cao, L. Miao, S. Tanemura, M. Tanemura, Y. Kuno, Y. Hayashi, Applied Physics Letters, 88 (2006) 251116-251116-251113.

[22] K. Mahmood, S.B. Park, J. Cryst. Growth, 347 (2012) 104-112.

[23] R. Swapna, M.C. Santhosh Kumar, Mater. Sci. Eng., B, 178 (2013) 1032-1039.

[24] M. Zheng, J. Wu, Appl. Surf. Sci., 255 (2009) 5656-5661.

[25] C. Shifu, Z. Wei, Z. Sujuan, L. Wei, Chem. Eng. J., 148 (2009) 263-269.

[26] C. Burda, X. Chen, R. Narayanan, M.A. El-Sayed, Chem. Rev., 105 (2005) 1025-1102.

[27] B. Liu, H.C. Zeng, Nano Res, 2 (2009) 201-209.

[28] H. Zhou, Z. Li, Mater. Chem. Phys., (2005) 326-331.

[29] S.-K. Mina, R.S. Manea, O.-S. Joob, T. Ganesha, B.W. Choc, S.-H. Han, Curr. Appl. Phys., 9 (2009) 492-495.

[30] Y. Li, C.-S. Liu, Trans. Nonferrous Met. Soc. China, 19 (2009) 399-403.

[31] Z.Z. Xu, Y. Ben, Z.L. Chen, F. Qi, Mater. Res. Bull., 48 (2013) 1725-1727.

[32] F.A. Sigoli, M.R. Davolos, M.J. Jr., J. Alloys Compd., 262-263 (1997) 292-295.

[33] L. Wang, M. Muhammed, J. Mater. Chem., 9 (1999) 2871-2878.

[34] Y. Liu, Z. Liu, G. Wang, J. Cryst. Growth, 252 (2003) 213-218.

[35] K.L. Meagley, S.P. Garcia, Cryst. Growth Des., 12 (2012) 707-713.

[36] M. Andrés-Vergés, M. Martínez-Gallego, J. Mater. Sci., 27 (1992) 3756-3762.

[37] V. Noack, A. Eychmüller, Chemistry of Materials, 14 (2002) 1411-1417.

[38] S.R. Petrusenko, V.N. Kokozei, Zh. Neorg. Khim., 41 (1996) 1238-1240.

[39] J.I. Langford, A.J.C. Wilson, J. Appl. Crystallogr., 11 (1978) 102-113.

[40] XRD Single-Crystal Software, Bruker Analytical X-ray Systems, Madison, WI, 1999.

[41] D.K. Schroder, Semiconductor Material and Device Characterization, Wiley-Interscience, 2006, pp. 39-40.

[42] S. Hénaux, F. Mondon, F. Gusella, I. Kling, G. Reimbold, J. Electrochem. Soc., 146 (1999) 2737-2743.

[43] G. Guilera, J.W. Steed, Chem. Commun., (1999) 1563-1564.

[44] H. Mimoun, J.Y.d.S. Laumer, L. Giannini, R. Scopelliti, C. Floriani, J. Am. Chem. Soc., 121 (1999) 6158-6166.

[45] Q.-H. Zhao, H.-F. Li, Y.-P. Ma, R.-B. Fang, Polish J. Chem., 76 (2002) 497-502. 
[46] L. Cheng, Y.-Y. Sun, Y.-W. Zhang, G.Q. Xu, Acta Cryst., Sect. E, E64 (2008) m1246m1246.

[47] W. Ostwald, Zeitschrift für physikalische Chemie, 22 (1897) 289-330.

[48] D. Wang, J. Zhang, Y. Peng, Z. Bi, X. Bian, X. Zhang, X. Hou, J. Alloys Compd. , 478 (2009) 325-329.

[49] J.L. Lyons, A. Janotti, C.G. Van de Walle, Applied Physics Letters, 95 (2009) 252105.

[50] Ü. Özgür, Y.I. Alivov, C. Liu, A. Teke, M.A. Reshchikov, S. Dog-brevean, V. Avrutin, S.J. Cho, H. Morko, J. Appl. Phys., 98 (2005) 041301.

[51] R.G. Southwick III, W.B. Knowlton, IEEE Transactions on Device and Materials Reliability, 6 (2006) 136-145.

[52] R.G. Southwick III, A. Sup, A. Jain, W.B. Knowlton, IEEE Transactions on Device and Materials Reliability, 11 (2011) 236 - 243.

[53] A. Janotti, C.G. Van de Walle, Rep. Prog. Phys., 72 (2009) 126501 (126529pp).

[54] N.P. Herring, L.S. Panchakarla, M.S. El-Shall, Langmuir, 30 (2014) 2230-2240. 


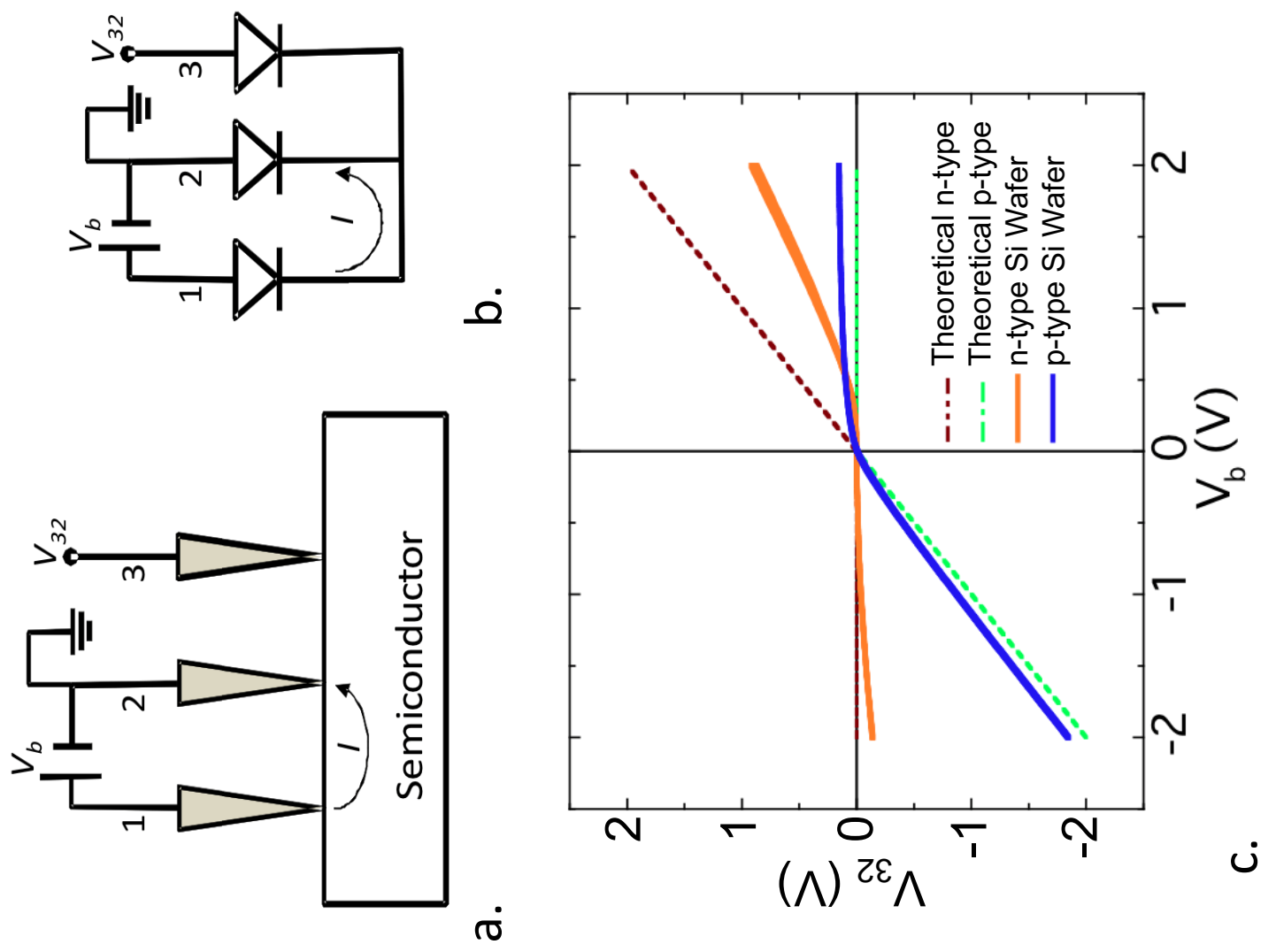


Figure 2

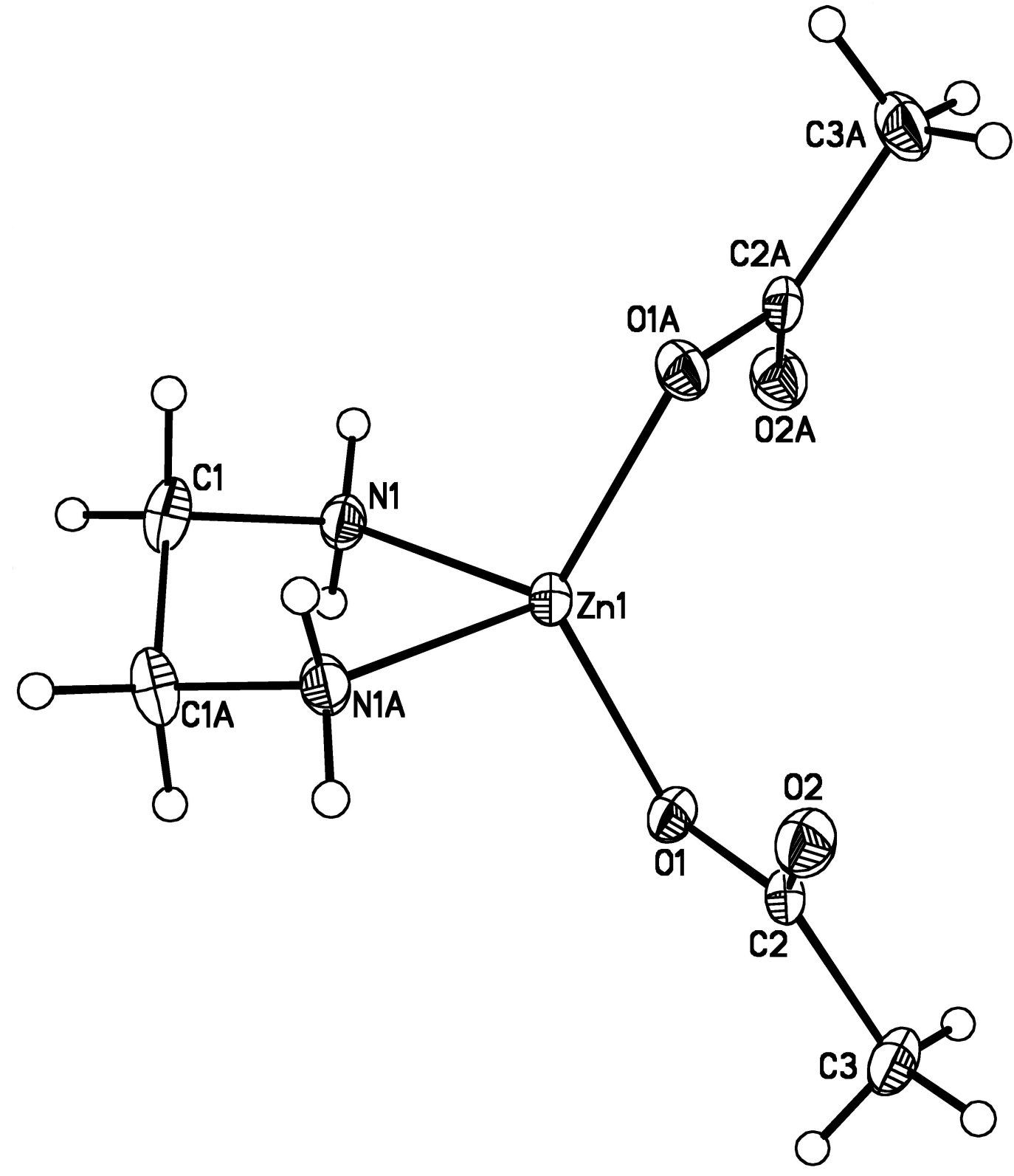




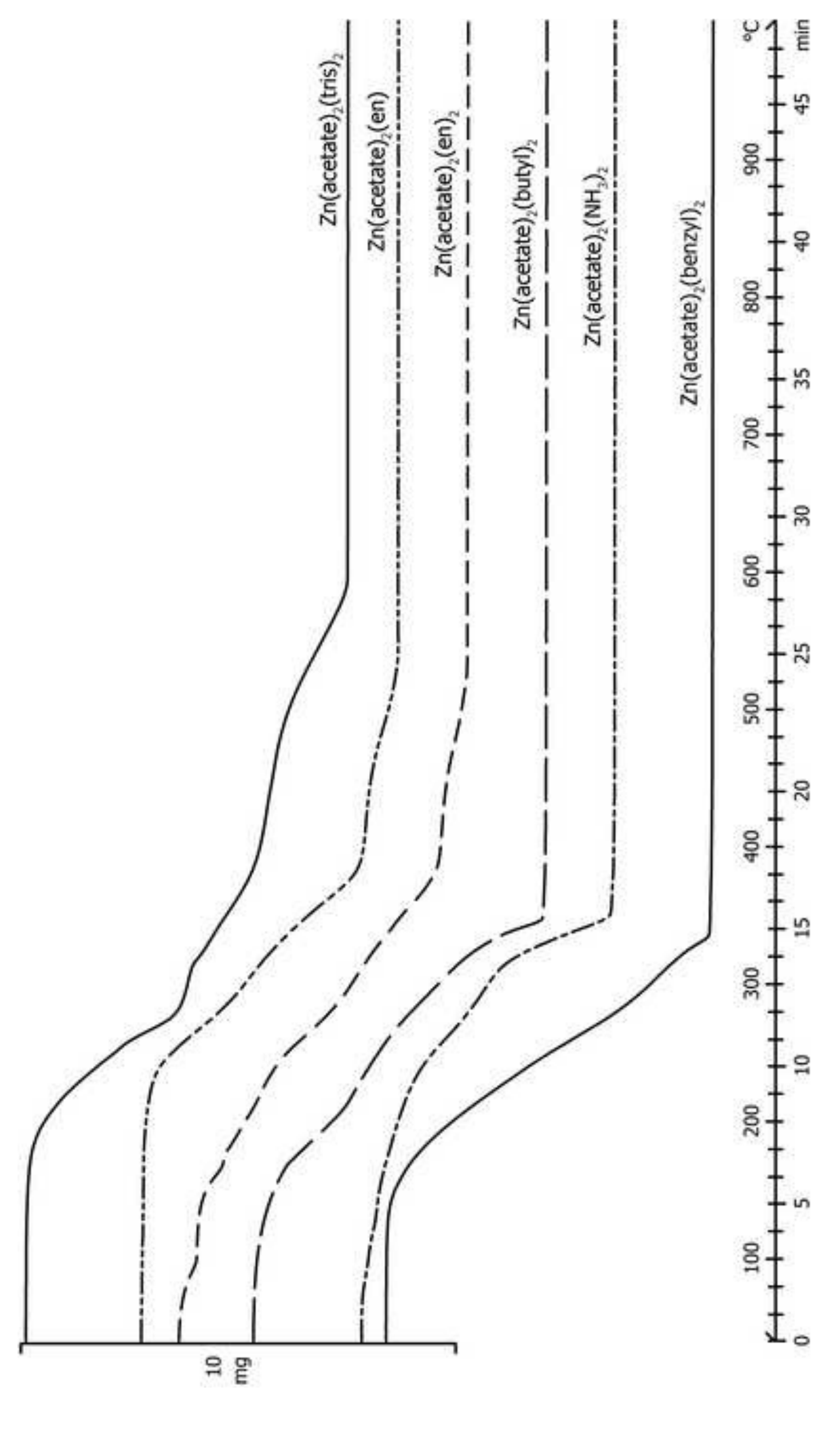




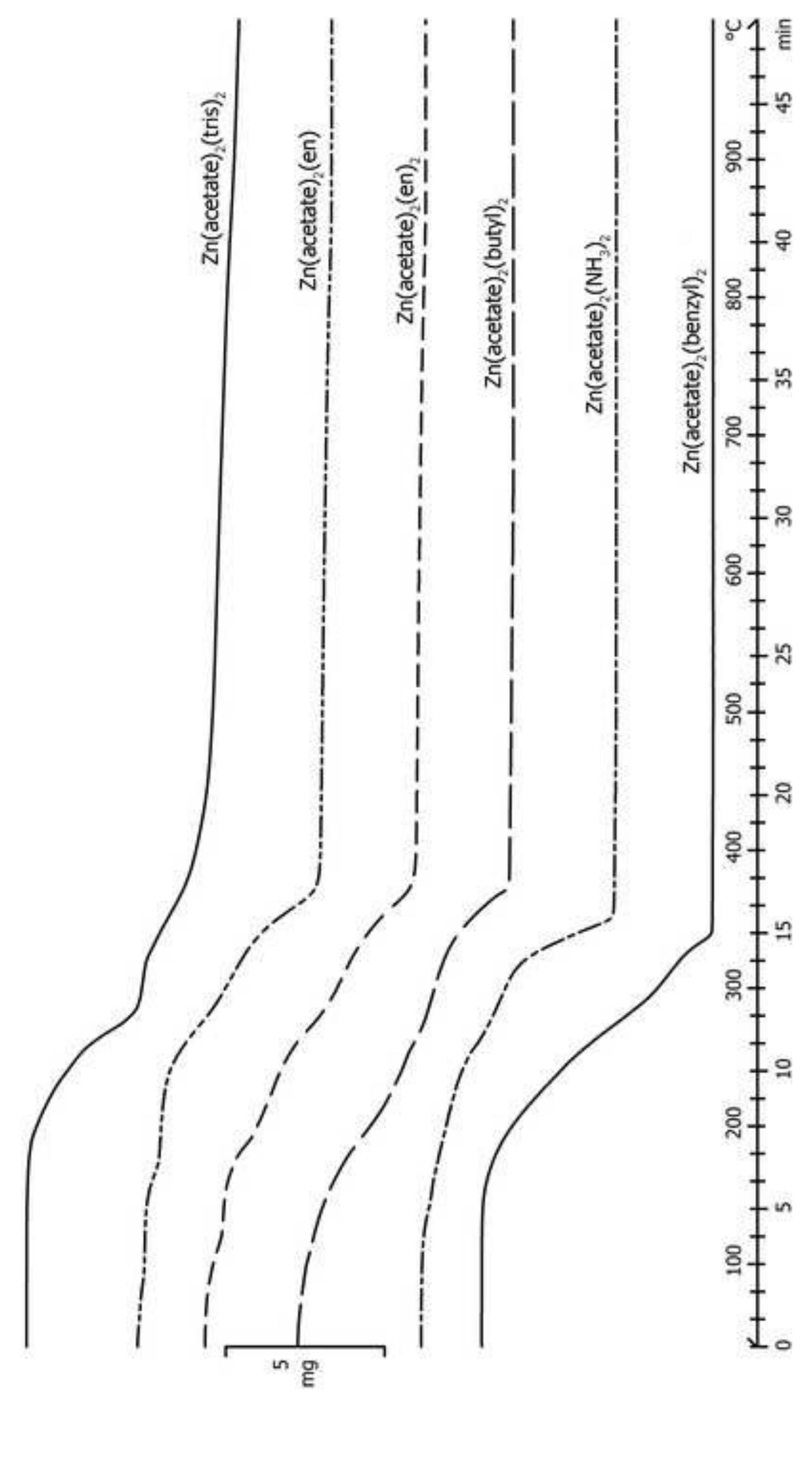




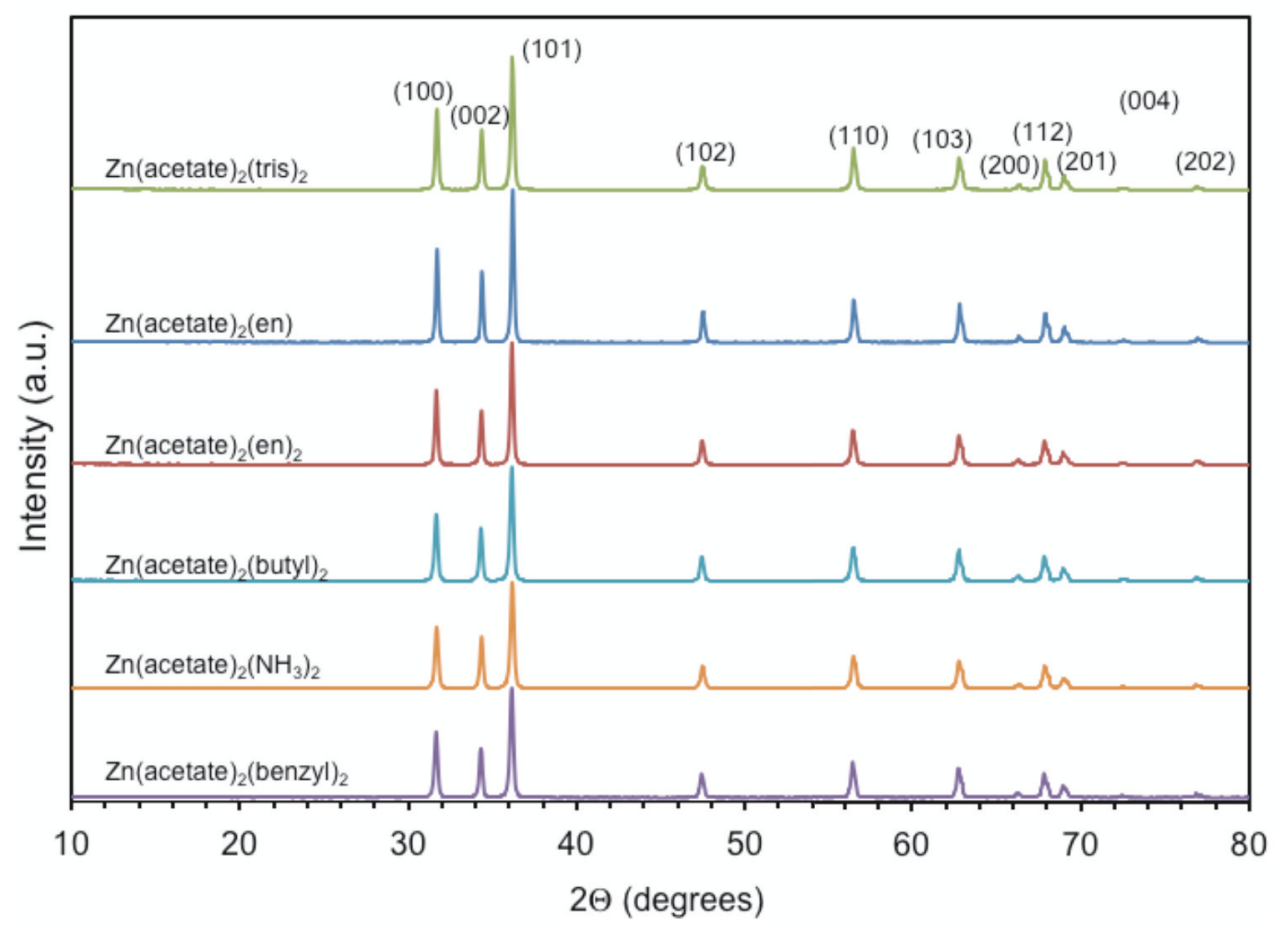

Figure 5.

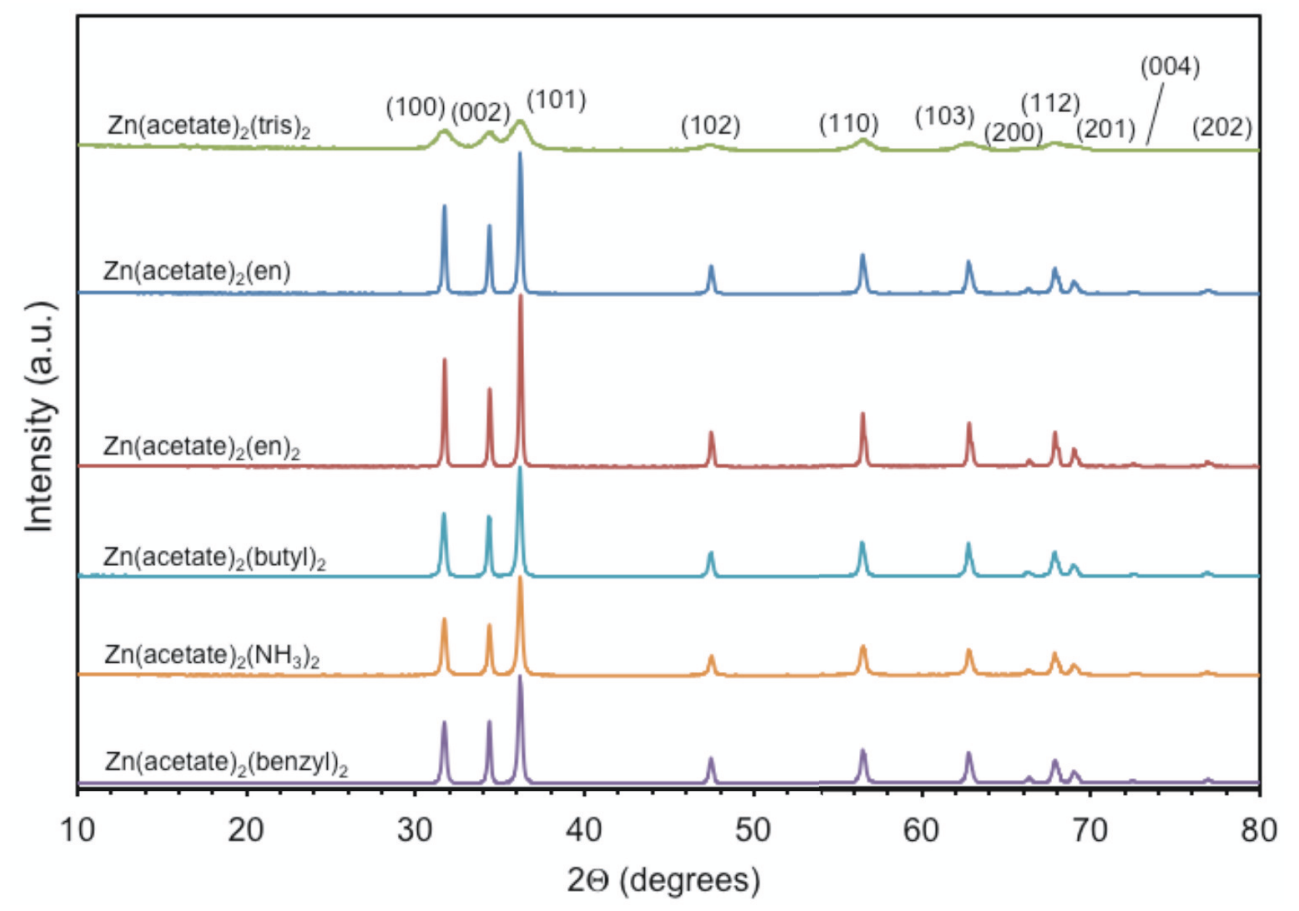

Figure 6. 


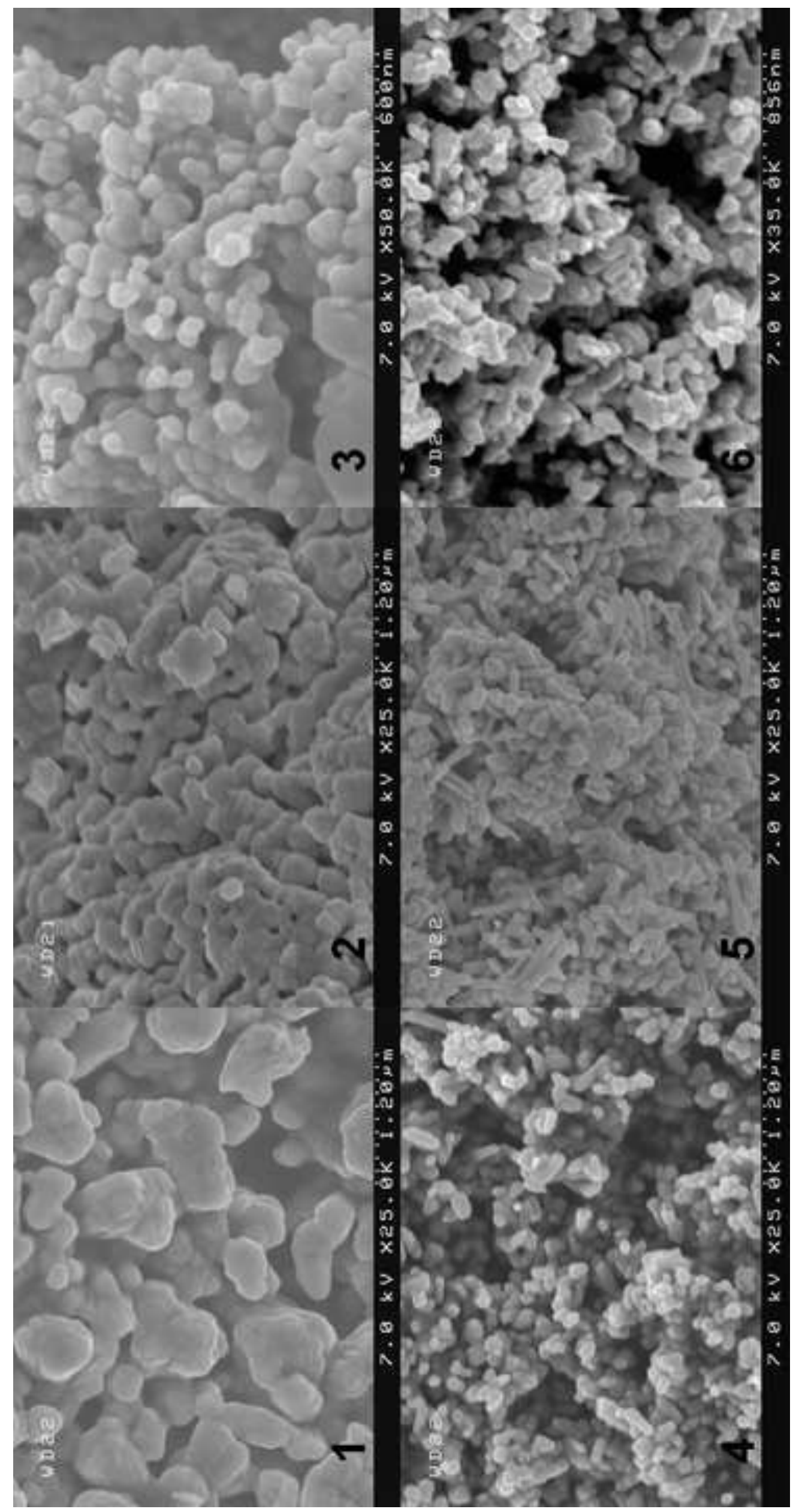





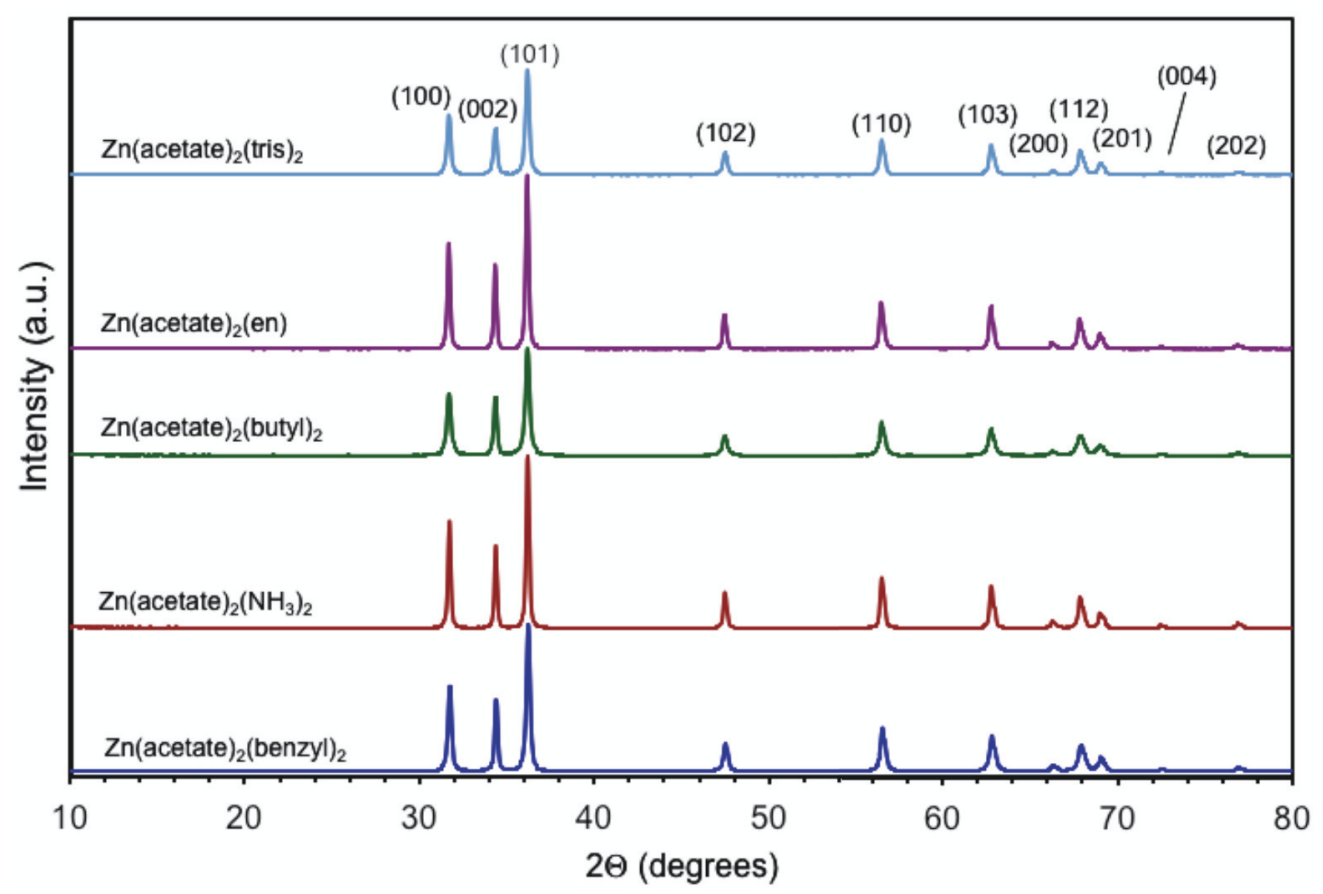

Figure 9. 


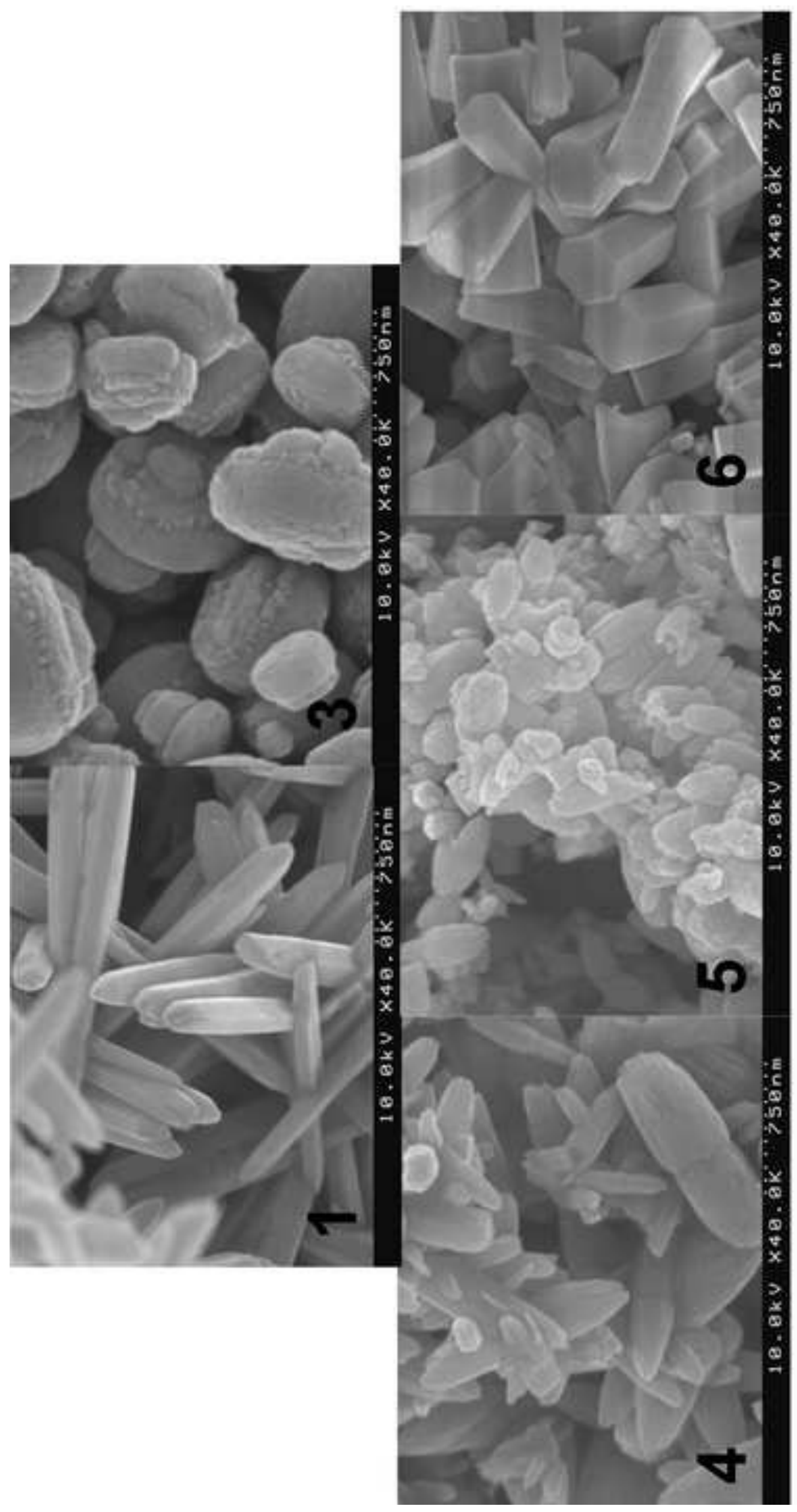




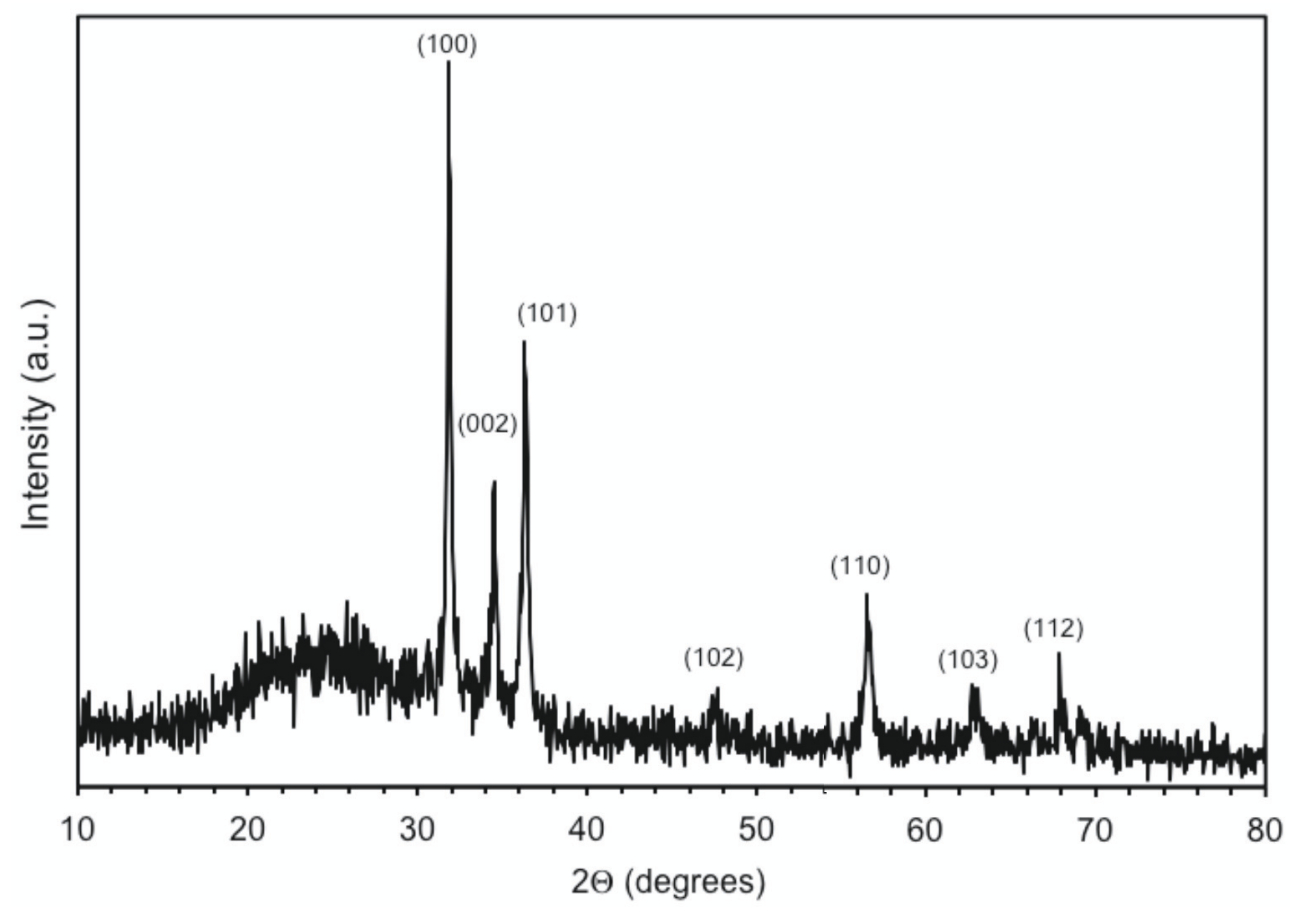

Figure 11. 
